\title{
Soil nitrogen oxide fluxes from lowland forests converted to smallholder rubber and oil palm plantations in Sumatra, Indonesia
}

\author{
Evelyn Hassler $^{1}$, Marife D. Corre ${ }^{1}$, Syahrul Kurniawan ${ }^{2}$, and Edzo Veldkamp ${ }^{1}$ \\ ${ }^{1}$ Soil Science of Tropical and Subtropical Ecosystems, Faculty of Forest Sciences and Forest Ecology, \\ University of Goettingen, Büsgenweg 2, 37077 Göttingen, Germany \\ ${ }^{2}$ Department of Soil Science, Faculty of Agriculture, University of Brawijaya, Jl. Veteran, 65145 Malang, Indonesia \\ Correspondence to: Evelyn Hassler (evelyn.hassler@ forst.uni-goettingen.de)
}

Received: 25 August 2016 - Discussion started: 7 September 2016

Revised: 10 April 2017 - Accepted: 16 April 2017 - Published: 7 June 2017

\begin{abstract}
Oil palm (Elaeis guineensis) and rubber (Hevea brasiliensis) plantations cover large areas of former rainforest in Sumatra, Indonesia, supplying the global demand for these crops. Although forest conversion is known to influence soil nitrous oxide $\left(\mathrm{N}_{2} \mathrm{O}\right)$ and nitric oxide (NO) fluxes, measurements from oil palm and rubber plantations are scarce (for $\mathrm{N}_{2} \mathrm{O}$ ) or nonexistent (for NO). Our study aimed to (1) quantify changes in soil-atmosphere fluxes of $\mathrm{N}$ oxides with forest conversion to rubber and oil palm plantations and (2) determine their controlling factors. In Jambi, Sumatra, we selected two landscapes that mainly differed in texture but were both on heavily weathered soils: loam and clay Acrisol soils. Within each landscape, we investigated lowland forests, rubber trees interspersed in secondary forest (termed as "jungle rubber"), both as reference land uses and smallholder rubber and oil palm plantations as converted land uses. In the loam Acrisol landscape, we conducted a followon study in a large-scale oil palm plantation (called PTPN VI) for comparison of soil $\mathrm{N}_{2} \mathrm{O}$ fluxes with smallholder oil palm plantations. Land-use conversion to smallholder plantations had no effect on soil $\mathrm{N}$-oxide fluxes $(P=0.58$ to 0.76 ) due to the generally low soil $\mathrm{N}$ availability in the reference land uses that further decreased with land-use conversion. Soil $\mathrm{N}_{2} \mathrm{O}$ fluxes from the large-scale oil palm plantation did not differ with those from smallholder plantations $(P=0.15)$. Over 1-year measurements, the temporal patterns of soil $\mathrm{N}$-oxide fluxes were influenced by soil mineral $\mathrm{N}$ and water contents. Across landscapes, annual soil $\mathrm{N}_{2} \mathrm{O}$ emissions were controlled by gross nitrification and sand content, which also suggest the influence of soil $\mathrm{N}$ and water availability. Soil $\mathrm{N}_{2} \mathrm{O}$ fluxes $\left(\mu \mathrm{N} \mathrm{m}^{-2} \mathrm{~h}^{-1}\right)$ were $7 \pm 2$ to
\end{abstract}

$14 \pm 7$ (reference land uses), $6 \pm 3$ to $9 \pm 2$ (rubber), $12 \pm 3$ to $12 \pm 6$ (smallholder oil palm) and $42 \pm 24$ (large-scale oil palm). Soil NO fluxes $\left(\mu \mathrm{g} \mathrm{N} \mathrm{m}^{-2} \mathrm{~h}^{-1}\right)$ were $-0.6 \pm 0.7$ to $5.7 \pm 5.8$ (reference land uses), $-1.2 \pm 0.5$ to $-1.0 \pm 0.2$ (rubber) and $-0.2 \pm 1.2$ to $0.7 \pm 0.7$ (smallholder oil palm). To improve the estimate of soil $\mathrm{N}$-oxide fluxes from oil palm plantations in this region, studies should focus on large-scale plantations (which usually have 2 to 4 times higher $\mathrm{N}$ fertilization rates than smallholders) with frequent measurements following fertilizer application.

\section{Introduction}

Expansion of industrial forestry and agriculture has caused rapid deforestation in Sumatra, Indonesia, resulting in a total primary forest loss of $36 \%$ between 1990 and 2010 (Margono et al., 2012). At present, most accessible lowland rainforests have been converted (Laumonier et al., 2010) into economically important crops, such as oil palm (Elaeis guineensis) and rubber (Hevea brasiliensis), with an area of 9.2 Mha (million hectare; BPS, 2016a). Indonesia is currently the principal oil palm producer and second largest rubber producer worldwide (FAO, 2016), and Sumatra is the most important contributor to the Indonesian production (BPS, 2016b). Despite the extent of land-use change in Sumatra, it is still uncertain how forest conversion will affect soil emissions of climate-relevant $\mathrm{N}$-oxide gases, nitrous oxide $\left(\mathrm{N}_{2} \mathrm{O}\right)$ and nitric oxide (NO). Only a few studies so far have reported soil $\mathrm{N}_{2} \mathrm{O}$ fluxes from forest conversion to these rapidly increasing and economically important land uses, oil 
palm and rubber, on lowland mineral soils in Southeast Asia (Aini et al., 2015; Ishizuka et al., 2002, 2005; Yashiro et al., 2008), and no study exists on soil NO fluxes.

Tropical forest soils are major sources of $\mathrm{N}_{2} \mathrm{O}$ and $\mathrm{NO}$, emitting $1.3 \mathrm{Tg} \mathrm{N}_{2} \mathrm{O}-\mathrm{N} \mathrm{yr}^{-1}$ (Werner et al., 2007) and 1.3 Tg NO-N yr$^{-1}$ (Davidson and Kingerlee, 1997) into the atmosphere, whereby considerable amounts of NO are expected to get redirected in forest systems since NO is easily oxidized to $\mathrm{NO}_{2}$ which, in turn, is absorbed by leaves (Jacob and Bakwin, 1991; Sparks et al., 2001). $\mathrm{N}_{2} \mathrm{O}$ is a potent greenhouse gas (IPCC, 2013) and is projected to be the single most important ozone-depleting substance throughout the 21st century (Ravishankara et al., 2009). NO plays an important role in the formation of tropospheric ozone, which in itself is an important greenhouse gas (Lammel and Graßl, 1995). $\mathrm{N}_{2} \mathrm{O}$ and $\mathrm{NO}$ are produced in soil by the microbial processes of nitrification and denitrification. The conceptual hole-in-the-pipe (HIP) model, which had been validated by studies in the tropics (Davidson et al., 2000), suggests that production and consumption of these gases in soils are influenced by two levels of control: first, the amount of soil available $\mathrm{N}$, and, second, the soil water content. HIP suggests that the higher the soil $\mathrm{N}$ availability is, the higher the soil N-oxide fluxes are and that well-aerated soil conditions (low moisture contents) favor for nitrification with $\mathrm{NO}$ as the main gaseous product, while with increasing water content denitrification with increasing proportion of $\mathrm{N}_{2} \mathrm{O}$ prevails (Davidson et al., 2000). Although there are other factors affecting soil $\mathrm{N}_{2} \mathrm{O}$ and $\mathrm{NO}$ fluxes through their influence on nitrification and denitrification (e.g., soil pH, temperature, bioavailable carbon; Firestone and Davidson, 1989; Heinen, 2006; Skiba and Smith, 2000), landscape-scale investigations in tropical areas show the dominant role of soil $\mathrm{N}$ availability and water content (Corre et al., 2014; Koehler et al., 2009; Müller et al., 2015).

Conversion of tropical forests to agricultural land uses generally alters soil $\mathrm{N}$-oxide fluxes through their effects on soil $\mathrm{N}$ availability and aeration as a consequence of management practices (e.g., fertilization, harvest, cultivation), which can add and export nutrients as well as compact or loosen the soil (Keller and Reiners, 1994; Veldkamp et al., 2008). In particular, the application of N-containing fertilizers can increase N-oxide emissions (Matson et al., 1996; Veldkamp et al., 1998), whereas agricultural land uses without fertilizer application lead to long-term reductions of soil $\mathrm{N}$-oxide fluxes or to comparably low-level fluxes as those from previous forests (Ishizuka et al., 2005; Keller and Reiners, 1994; Verchot et al., 1999). In tropical regions, it has been shown that soil $\mathrm{NO}$ and $\mathrm{N}_{2} \mathrm{O}$ emissions can be very high following fertilizer application, constituting $6.4-8.6 \%$ of applied $\mathrm{N}$ fertilizer especially at high fertilizer application rates (Veldkamp and Keller, 1997; Veldkamp et al., 1998).

For lowland forests on highly weathered soils in Sumatra, Indonesia, where our present study was conducted, it has been shown that soil $\mathrm{N}$ availability (with gross rates of ammonium, $\mathrm{NH}_{4}^{+}$, transformations as indices) is higher in the clay than in the loam Acrisol soils (Allen et al., 2015), suggesting that soil texture controls soil fertility, which in turn affects plant productivity, soil water holding capacity, decomposition and ultimately soil $\mathrm{N}$ cycling (Allen et al., 2015). Conversion of lowland forest and jungle rubber to oil palm and rubber on these Acrisol soils showed intermediate soil $\mathrm{N}$ availability in oil palm plantations due to abatement of soil fertility decline by low to moderate applications of fertilizers and lime, whereas the unfertilized rubber plantations displayed the lowest soil $\mathrm{N}$ availability and fertility in general (Allen et al., 2015).

Our present study focuses on soil $\mathrm{N}_{2} \mathrm{O}$ and $\mathrm{NO}$ fluxes from a region in Jambi, Sumatra, where increased deforestation for rubber and oil palm production has occurred in the last two decades. We covered four land uses within two landscapes on highly weathered soils that mainly differed in soil texture (clay and loam Acrisols): forest, rubber trees interspersed in secondary forest (hereafter, termed as jungle rubber) as the reference land uses, and smallholder rubber and oil palm plantations as the converted land uses. In addition, we conducted a follow-on study to evaluate the effect of $\mathrm{N}$ input rate on soil $\mathrm{N}_{2} \mathrm{O}$ fluxes by comparing a large-scale plantation (with 2-4 times higher fertilization rate) and smallholder plantations within the same landscape of the loam Acrisol soil. Based on the above-mentioned findings on soil $\mathrm{N}$ availability, we formulated two hypotheses: $(\mathrm{H} 1)$ soil $\mathrm{N}_{2} \mathrm{O}$ and NO fluxes from the reference land uses will be higher in the clay than the loam Acrisol landscape; and (H2) forest and jungle rubber will have the highest soil $\mathrm{N}_{2} \mathrm{O}$ and $\mathrm{NO}$ fluxes, followed by the smallholder oil palm plantations (fertilized at low to moderate rates), with the lowest fluxes from the unfertilized rubber plantations. Our study aimed to (1) quantify changes in soil-atmosphere fluxes of $\mathrm{N}$ oxides with forest conversion to smallholder oil palm and rubber plantations, (2) determine the temporal controls of soil N-oxide fluxes measured within 1 year and (3) assess landscape-scale controlling factors of annual soil $\mathrm{N}_{2} \mathrm{O}$ fluxes from converted lowland landscapes in Sumatra, Indonesia. Our study contributes to the much needed information on soil N-oxide fluxes from these economically and globally relevant tropical land uses.

\section{Material and methods}

\subsection{Study area, experimental design and management practices}

The study region is situated in Jambi province, Sumatra, Indonesia $\left(2^{\circ} 0^{\prime} 57^{\prime \prime} \mathrm{S}, 103^{\circ} 15^{\prime} 33^{\prime \prime} \mathrm{E}\right.$; elevation of $73 \pm 3 \mathrm{~m}$ above sea level), where conversion of forest to rubber and oil palm plantations is widespread. The area has a mean annual temperature of $26.7 \pm 0.1{ }^{\circ} \mathrm{C}$ and a mean annual precipitation of $2235 \pm 381 \mathrm{~mm}$ (1991-2011; data from a climatological 
station at the Jambi Sultan Thaha Airport). During our study year (2013), annual rainfall in the study region was 3418$3475 \mathrm{~mm}$ (data from climatological stations at the Harapan Rainforest, Sarolangun and Lubuk Kepayang, approximately $10-20 \mathrm{~km}$ from our sites), which was higher than the longterm average. Total dissolved $\mathrm{N}$ deposition via rainfall was between $12.9 \pm 0.1$ and $16.4 \pm 2.6 \mathrm{~kg} \mathrm{~N} \mathrm{ha}^{-1} \mathrm{yr}^{-1}$, measured at two locations in the study region during 2013 (Kurniawan, 2016).

We delineated the study region in two landscapes, which had the same highly weathered soil group but mainly differed in soil texture: clay and loam Acrisol soils. The clay Acrisol soil had a larger $\mathrm{pH}(4.5 \pm 0.0)$, base saturation $(23 \pm 6 \%)$ and Bray-extractable $\mathrm{P}\left(1.4 \pm 0.1 \mathrm{~g} \mathrm{P} \mathrm{m}^{-2}\right)$, and lower Al saturation $(61 \pm 3 \%)$ in the top $10 \mathrm{~cm}$ depth compared to the loam Acrisol soil $(4.3 \pm 0.0 \mathrm{pH}, 11 \pm 1 \%$ base saturation, $0.5 \pm 0.1 \mathrm{~g} \mathrm{P} \mathrm{m}^{-2}$ and $80 \pm 1 \% \mathrm{Al}$ saturation; all $P \leq 0.05$ Allen et al., 2015). In the first part of our study, we investigated four land-use types within each landscape: lowland forest, jungle rubber, both as the reference land uses, and smallholder monoculture plantations of rubber and oil palm, as the converted land uses. Each land use within each landscape had four sites as replicates, and we laid out a $50 \mathrm{~m} \times 50 \mathrm{~m}$ plot in each replicate site; in total we had 32 plots. Within each plot, a $10 \times 10$ grid was established and we randomly selected four subplots $(5 \mathrm{~m} \times 5 \mathrm{~m}$ each $)$ per plot, each with one permanently installed chamber base for measurements of soil N-oxide fluxes. All measurements (see Sect. 2.2) were conducted in 2013 (Appendix Table A1). A more detailed description of the study sites and plot design was reported earlier by Allen et al. (2015) and Hassler et al. (2015).

The second part was a follow-on study, wherein we conducted additional measurements in a large-scale oil palm plantation (called PTPN VI) in the loam Acrisol landscape from 2014 to 2015 in order to compare with the smallholder oil palm plantations within the same landscape (Appendix Table A1). In the PTPN VI site, we selected four replicates at a distance of $50 \mathrm{~m}$ apart. At each replicate, we installed three permanent chamber bases at $0.8,2.8$ and $4.8 \mathrm{~m}$ from the tree base in order to characterize possible spatial variation caused by management practices within each replicate.

Based on our interviews with the smallholders, the monoculture plantations were established after clearing and burning of either forest or jungle rubber, and hence these land uses served as the reference land uses with which the converted plantations were compared. Additionally, the comparability of initial soil conditions between the reference and converted land uses was tested based on a land-use-independent soil characteristic, i.e., clay content at a $0.5-2 \mathrm{~m}$ depth, which did not statistically differ among land uses within each landscape (Allen et al., 2015; Hassler et al., 2015). Thus, changes in soil N-oxide fluxes can be attributed to land-use change with its associated management practices. The plantations' ages ranged between 7 and 17 years, and tree density, tree height, basal area and tree species abundance were higher in the reference land uses than the monoculture plantations (all reported by Allen et al., 2015; Hassler et al., 2015; Kotowska et al., 2015).

Management practices in the plantations included manual harvest, weeding and fertilizer application (details reported by Hassler et al., 2015). In 2013, fertilization in the smallholder oil palm plantations was conducted one to two times per year, and fertilization rates ranged between $48-88 \mathrm{~kg} \mathrm{~N} \mathrm{ha}^{-1} \mathrm{yr}^{-1}$ (except two smallholders who applied $138 \mathrm{~kg} \mathrm{Nha}^{-1} \mathrm{yr}^{-1}$ ), 21-38 $\mathrm{kg} \mathrm{Pha}^{-1} \mathrm{yr}^{-1}$ and 40$157 \mathrm{~kg} \mathrm{~K} \mathrm{ha}^{-1} \mathrm{yr}^{-1}$, with the lower range in the clay Acrisol and the upper range in the loam Acrisol. The fertilizer sources were NPK complete, urea and $\mathrm{KCl}$. One of the smallholders in the loam Acrisol landscape applied $200 \mathrm{~kg}$ dolomite $\mathrm{ha}^{-1} \mathrm{yr}^{-1}$. Fertilizers were applied around each palm tree at about $0.8-1 \mathrm{~m}$ from the stem base (Hassler et al., 2015). Rubber plantations were not fertilized. In the large-scale oil palm plantation, fertilizer application rates were typically higher than those in smallholder plantations; fertilizers were applied once in 2014 at the rates of $196-36-206 \mathrm{~kg} \mathrm{~N}, \mathrm{P}$ and $\mathrm{K} \mathrm{ha}^{-1} \mathrm{yr}^{-1}$, with also $602 \mathrm{~kg}$ dolomite $\mathrm{ha}^{-1} \mathrm{yr}^{-1}$, and once before the end of our measurements in July 2015 at the rates of $96-23-96 \mathrm{~kg} \mathrm{~N}$, $\mathrm{P}$ and $\mathrm{Kha}^{-1} \mathrm{yr}^{-1}$. The fertilizer forms were NPK complete, urea, triple superphosphate and $\mathrm{KCl}$. Application in this large-scale plantation was done partly manually by applying the fertilizers at a $1 \mathrm{~m}$ distance to the tree base and partly mechanically by broadcasting the fertilizer within a 1-3 $\mathrm{m}$ distance from the palm rows. In 2015, fertilizers were mainly mechanically broadcasted within these inter-rows.

\subsection{Soil N-oxide fluxes and supporting soil factors}

In the first part of our study, soil $\mathrm{N}_{2} \mathrm{O}$ fluxes were measured in all land uses (32 plots) at monthly intervals from December 2012 to December 2013, whereas soil NO fluxes were measured four times between March and September 2013 (Appendix Table A1). Two forest sites and one jungle rubber site in the clay Acrisol landscape were not measured for soil NO fluxes due to difficulty in accessing these sites, which did not allow us to stabilize the NO detector during transport in the field (i.e., using motorcycles on very rugged trails). Soil $\mathrm{NO}$ fluxes were not measured as frequently as $\mathrm{N}_{2} \mathrm{O}$ fluxes because these fluxes were always very low at all sites and we decided to stop this measurement in September 2013. In the follow-on study, soil $\mathrm{N}_{2} \mathrm{O}$ fluxes were measured more frequently (biweekly from July 2014 to July 2015; Appendix Table A1) in a large-scale oil palm plantation (in congruence with its high fertilizer application rate) to compare with the smallholder oil palm plantations within the same landscape of the loam Acrisol soil.

For the first part of our study, we used randomly installed chamber bases (inserted to $\sim 0.03 \mathrm{~m}$ depth with distances to the tree base between 1.8 and $5 \mathrm{~m}$; see Sect. 2.1) with monthly measurements, which may have missed the 
$\mathrm{N}$-fertilizer-induced pulse of soil $\mathrm{N}$-oxide emissions in the smallholder oil palm plantations (Veldkamp and Keller, 1997; Veldkamp et al., 1998). Therefore, we conducted more intensive measurements of soil $\mathrm{N}_{2} \mathrm{O}$ fluxes during the 3 to 8.5 weeks (with 6 to 11 sampling days) following fertilizer application at three of the smallholder oil palm plantations within each landscape. These measurements served to characterize the short-term, N-fertilizerinduced contribution (e.g., Koehler et al., 2009) to total $\mathrm{N}_{2} \mathrm{O}$ fluxes. Soil NO fluxes were also measured during 6 to 8.5 weeks (with 9 to 10 sampling days) following fertilizer application at one of the smallholder oil palm plantations within each landscape. Measurements in the three smallholder oil palm plantations at each landscape were conducted during October-December 2013, January-March 2014 and February-April 2014 (Appendix Table A1). We applied the same fertilizer forms, rates and methods as used by the smallholders. Three oil palm trees were selected in each of the six sites. In the clay Acrisol landscape, $2 \mathrm{~kg}$ of complete NPK fertilizer (equivalent to $0.32 \mathrm{~kg} \mathrm{~N}$ tree ${ }^{-1}$ ) was applied to each tree, whereas in the loam Acrisol, $2 \mathrm{~kg}$ of combined complete $\mathrm{NPK}$, ammonium sulfate and $\mathrm{KCl}$ fertilizers (equivalent to $0.26 \mathrm{~kg} \mathrm{~N}$ tree $^{-1}$ ) was applied to each tree. The fertilizer was applied within a $0.8-1 \mathrm{~m}$ distance from the tree base. We installed three permanent chamber bases at various distances from the tree base: $0.3 \mathrm{~m}$ from the tree base (F1 is the chamber location with incidental fertilization), $0.8 \mathrm{~m}$ from the tree base that was on the fertilized area (F2 is the fertilized chamber location) and 4-4.5 $\mathrm{m}$ from the tree base that was in the middle of the inter-rows and served as the reference chamber without fertilizer application (NF is the non-fertilized chamber location).

Soil $\mathrm{N}_{2} \mathrm{O}$ fluxes were measured using the same methods employed in our earlier studies (e.g., Corre et al., 2014; Koehler et al., 2009). During gas sampling, the permanently installed chamber bases were covered with vented static, polyethylene hoods (chamber area of $0.05 \mathrm{~m}^{2}$ and total volume of $12 \mathrm{~L})$, and four gas samples ( $30 \mathrm{~mL}$ each) were taken at 1, 11, 21 and 31 min after chamber closure by connecting a syringe with a Luer lock to the chamber sampling port. Gas samples were immediately injected into pre-evacuated $12 \mathrm{~mL}$ Labco exetainers sealed with rubber septa (Labco Limited, Lampeter, UK), maintaining an overpressure; these exetainers have been tested by our group to be leak proof during extended period of storage (e.g., up to 6 months; Hassler et al., 2015). Within 3-4 months the gas samples were transported by airfreight to Germany and were analyzed upon arrival using a gas chromatograph with an electron capture detector (GC 6000 Vega Series 2, Carlo Erba Instruments, Milan, Italy). For the measurements from March to July 2015 in the large-scale oil palm plantation, the gas samples were analyzed with another gas chromatograph (SRI 8610C, SRI Instruments Europe GmbH, Bad Honnef, Germany), which had been previously cross calibrated using the same standards. For calibration, three standard gases were used with concen- trations of 360, 1000 and 1600 ppb $\mathrm{N}_{2} \mathrm{O}$ (Deuste Steininger GmbH, Mühlhausen, Germany).

Soil NO fluxes were measured (described in detail in our earlier works, e.g., Corre et al., 2014; Koehler et al., 2009) using the same chamber bases described above. During measurements, the chamber bases were covered with vented dynamic, polyethylene hoods (total volume of $12 \mathrm{~L}$ ), and NO concentrations were measured in situ during 5-7 min following chamber closure using a Scintrex LMA-3 chemiluminescence detector (Scintrex, Ontario, Canada) in which NO is oxidized to $\mathrm{NO}_{2}$ by a $\mathrm{CrO}_{3}$ catalyst, after which it reacts with a luminol solution. Calibration of the NO detector was carried out at each site prior to and after measurements using a two-point calibration of a standard gas with $3000 \mathrm{ppb}$ NO (Deuste Steininger GmbH, Mühlhausen, Germany) which was diluted using dried ambient air. NO measurements were recorded every $5 \mathrm{~s}$ using a data logger (CR510, Campbell Scientific, Logan, USA).

Soil $\mathrm{N}_{2} \mathrm{O}$ and NO fluxes were calculated from the linear increase of concentration over time of chamber closure and adjusted for air temperature and atmospheric pressure, measured at each site on each sampling day. Annual soil $\mathrm{N}_{2} \mathrm{O}$ fluxes from the monthly sampling at each site were estimated using the trapezoidal rule, which is an interpolation between measured fluxes and the interval between sampling days. Interpolated fluxes were summed for the entire year (e.g., Hassler et al., 2015). Annual NO fluxes were not calculated, since we only conducted four measurement periods for each plot as explained above. To calculate the $\mathrm{N}$-fertilizerinduced pulse of soil $\mathrm{N}$-oxide fluxes, we also used the trapezoidal rule on day intervals between measured flux rates to estimate the total flux during the entire period following fertilizer application, covering the pre-fertilizer level, the peak and the return to background levels of soil $\mathrm{N}$-oxide fluxes. We calculated the percentage of combined soil $\mathrm{NO}$ and $\mathrm{N}_{2} \mathrm{O}$ emissions from the applied $\mathrm{N}$-fertilizer rate at each site as follows:

The percentage (\%) $\mathrm{NO}-\mathrm{N}+\mathrm{N}_{2} \mathrm{O}-\mathrm{N}$ of $\mathrm{N}$ applied $\quad \mathrm{yr}^{-1}=\left(\mathrm{NO}-\mathrm{N}+\mathrm{N}_{2} \mathrm{O}-\mathrm{N}\right.$ fluxes from $\mathrm{F} 1$ and $\mathrm{F} 2$ chambers $-\mathrm{NO}-\mathrm{N}+\mathrm{N}_{2} \mathrm{O}-\mathrm{N}$ fluxes from $\mathrm{NF}$ chamber) $\times$ frequency of fertilization $\mathrm{yr}^{-1} \times$ fertilized area $\left(\mathrm{m}^{2} \mathrm{ha}^{-1}\right) / \mathrm{N}$ fertilization rate $\left(\mathrm{kg} \mathrm{N} \mathrm{ha}^{-1} \mathrm{yr}^{-1} \times 10^{9} \mu \mathrm{g} \mathrm{kg}^{-1}\right) \times 100$,

where $\mathrm{NO}-\mathrm{N}+\mathrm{N}_{2} \mathrm{O}-\mathrm{N}$ is expressed in $\mu \mathrm{g} \mathrm{N} \mathrm{m}{ }^{-2}$ for the entire period of the fertilizer effect. In this calculation, we included fluxes from chamber location F1 in order to include any incidental fertilizer application to this area (possibly from previous applications by the smallholders and possible redistribution of applied nutrients within the soil), since $\mathrm{N}$-oxide fluxes from chamber location F1 were often higher than those from NF chambers (see Sect. 3.2).

Soil factors known to control soil N-oxide fluxes, i.e., temperature, water-filled pore space (WFPS), and extractable $\mathrm{NH}_{4}^{+}$and nitrate $\left(\mathrm{NO}_{3}^{-}\right)$, were measured within the top $0.05 \mathrm{~m}$ depth during each soil $\mathrm{N}$-oxide flux measurement at 

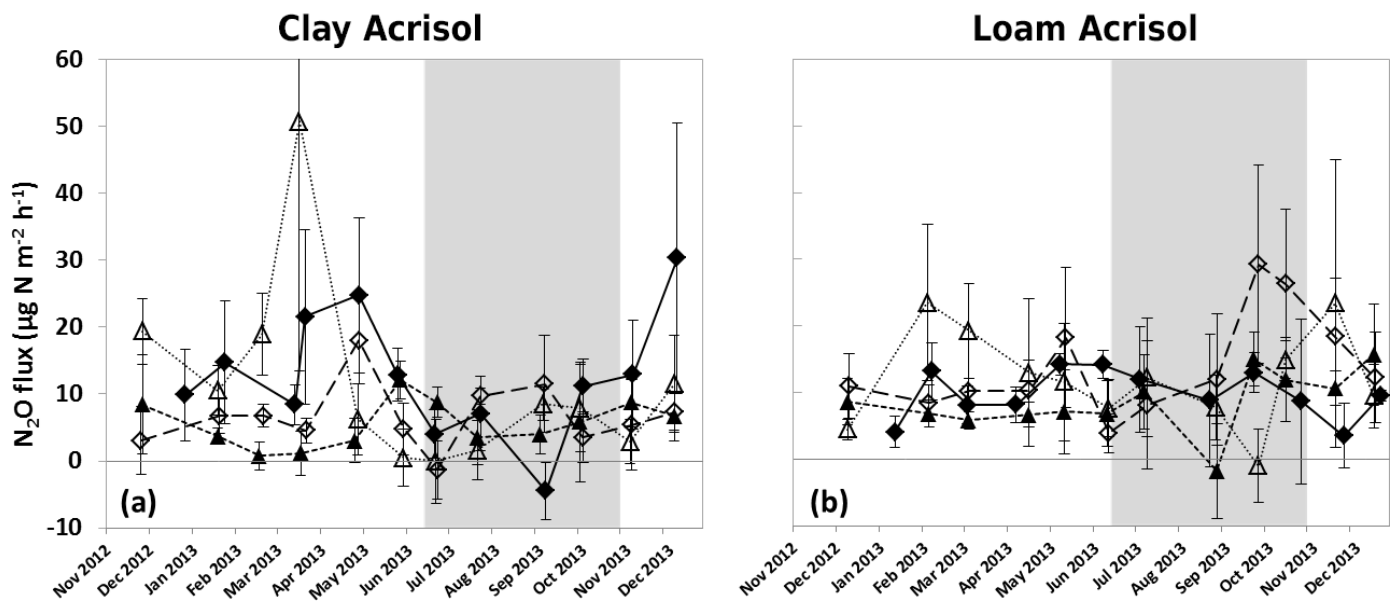

Figure 1. Mean $\left( \pm \mathrm{SE}, n=4\right.$ sites) soil $\mathrm{N}_{2} \mathrm{O}$ fluxes from forest $(\diamond)$, jungle rubber $(\diamond)$, rubber $(\boldsymbol{\Delta})$ and oil palm $(\triangle)$, located within the clay $(\mathbf{a})$ and loam Acrisol (b) landscapes in Jambi, Indonesia. Measurements were carried out monthly from December 2012 to December 2013; gray shadings mark the dry season.

all 32 sites and at the 6 sites of smallholder oil palm plantations following fertilization. Soil temperature was measured close to each chamber base using a digital thermometer. Soil samples were taken at $1 \mathrm{~m}$ distance from the four chambers, pooled, mixed thoroughly and subsampled for immediate extraction of mineral $\mathrm{N}$ in the field, using prepared extraction bottles containing $150 \mathrm{~mL} 0.5 \mathrm{M} \mathrm{K}_{2} \mathrm{SO}_{4}$. Upon arrival at the field station, extraction bottles were shaken for $1 \mathrm{~h}$ and filtered, and extracts were frozen immediately. The remaining soil sample was used to determine the gravimetric moisture content (by oven-drying for at least 1 day at $105^{\circ} \mathrm{C}$ ), whereby WFPS was calculated using a particle density of $2.65 \mathrm{~g} \mathrm{~cm}^{-3}$ for mineral soil and the measured soil bulk density at our study sites (Allen et al., 2015). Concurrent to the measurements following the fertilizer applications, soil was sampled close to each of the chamber locations, F1, F2 and $\mathrm{NF}$ (described above), and was processed separately for mineral $\mathrm{N}$ extraction and WFPS determination. Frozen extracts were transported by airfreight to Germany and analyzed for $\mathrm{NH}_{4}^{+}$and $\mathrm{NO}_{3}^{-}$concentrations using continuous flow injection colorimetry (SEAL Analytical AA3, SEAL Analytical $\mathrm{GmbH}$, Norderstedt, Germany), as described in detail by Hassler et al. (2015).

In addition, soil physical and biochemical parameters within the top $0.1 \mathrm{~m}$ were measured once in 2013 at all 32 plots (i.e., soil $\mathrm{N}$-cycling processes, including gross nitrification as one of the indices of $\mathrm{N}$ availability in the soil, microbial biomass, total organic $\mathrm{C}$, total $\mathrm{N}$, exchangeable cations, $\mathrm{pH}$, soil texture and soil bulk density), reported by Allen et al. (2015). We used these soil parameters to analyze their relationships (see Sect. 2.3) with annual soil $\mathrm{N}_{2} \mathrm{O}$ fluxes and reported the parameters that showed significant relationships with annual soil $\mathrm{N}_{2} \mathrm{O}$ fluxes in Appendix Table A2.

\subsection{Statistical analysis}

We first tested each parameter for normal distribution (Shapiro-Wilk's test) and equality of variance (Levene's test), and a logarithmic transformation was applied when these assumptions were not met. Linear mixed-effect (LME) models (Crawley, 2007) were used to assess differences in Noxide fluxes between landscapes for the reference land uses (testing H1) or to assess differences in $\mathrm{N}$-oxide fluxes among land uses within each landscape (testing H2). Furthermore, an LME model was applied to assess differences in soil $\mathrm{N}_{2} \mathrm{O}$ fluxes between the smallholder and large-scale oil palm plantations (as a follow-on study) within the loam Acrisol landscape. The LME models were also used to asses fertilization effects (i.e., as represented by the chamber locations F1, F2 and $\mathrm{NF}$ ) on soil $\mathrm{N}$-oxide fluxes from smallholder oil palm plantations and to test differences in $\mathrm{N}$-oxide fluxes between landscapes following fertilization for chamber locations F1 and F2. The detailed descriptions of the LME models are provided in Appendix A. Significant differences were based on the analysis of variance with Fisher's least significant difference (LSD) test for multiple comparisons. We set the statistical significance at $P \leq 0.05$, and, only for a few specified parameters, we also considered marginal significance at $P \leq 0.09$ because our experimental design encompassed the inherently high spatial variability in our study area (e.g., Hassler et al., 2015).

To assess the temporal relationships between soil $\mathrm{N}$-oxide fluxes and soil factors (temperature, WFPS, $\mathrm{NO}_{3}^{-}$and $\mathrm{NH}_{4}^{+}$), we used the means of the replicate plots per land use on each of the 12 monthly measurements and conducted Pearson's correlation test separately for the reference land uses (forest and jungle rubber, $\left.n=48\left(\mathrm{~N}_{2} \mathrm{O}\right), n=16(\mathrm{NO})\right)$ and the converted land uses (rubber and oil palm, $n=48\left(\mathrm{~N}_{2} \mathrm{O}\right), n=16$ (NO)) across landscapes for the whole year. Similarly, for 
Table 1. Mean ( \pm SE, $n=4$ sites) soil $\mathrm{N}_{2} \mathrm{O}$ (with 12 monthly measurements) and NO fluxes (with four monthly to bimonthly measurements) as well as annual soil $\mathrm{N}_{2} \mathrm{O}$ fluxes from different land uses within each landscape in Jambi, Indonesia. Means followed by different lowercase letters indicate significant differences among land uses within each landscape and different capital letters indicate significant differences between landscapes within each land use (linear mixed-effect models with Fisher's LSD test at $P \leq 0.09$ ). For soil NO fluxes in the clay Acrisol, forest was excluded in the comparison among land uses because measurements were only carried out in two sites. Annual soil $\mathrm{N}_{2} \mathrm{O}$ fluxes are calculated from the monthly fluxes using the trapezoidal rule. For smallholder oil palm plantations, values in italics were the fertilizer-induced annual soil $\mathrm{N}_{2} \mathrm{O}$ fluxes (see Sect. 2.2). In the loam Acrisol landscape, soil $\mathrm{N}_{2} \mathrm{O}$ fluxes were additionally measured in a large-scale oil palm plantation (mean $\pm \mathrm{SE}, n=4$ replicates); these fluxes did not differ from those of smallholder plantations within the same landscape (linear mixed-effect models with Fisher's LSD test; $P=0.15$ ).

\begin{tabular}{lrrr}
\hline $\begin{array}{l}\text { Land-use } \\
\text { type }\end{array}$ & $\begin{array}{r}\mathrm{N}_{2} \mathrm{O} \text { fluxes } \\
\left(\mu \mathrm{N} \mathrm{m}^{-2} \mathrm{~h}^{-1}\right)\end{array}$ & $\begin{array}{r}\mathrm{NO}^{-1} \text { fluxes } \\
\left(\mu \mathrm{N} \mathrm{m}^{-2} \mathrm{~h}^{-1}\right)\end{array}$ & $\begin{array}{r}\text { Annual } \mathrm{N}_{2} \mathrm{O} \text { fluxes } \\
\left(\mathrm{kg} \mathrm{Nha}^{-1} \text { year }^{-1}\right)\end{array}$ \\
\hline Clay Acrisol landscape & & & \\
\hline Forest & $12.8 \pm 5.6^{\mathrm{a}, \mathrm{A}}$ & $(1.7 \pm 0.3)$ & $1.0 \pm 0.4$ \\
Jungle rubber & $6.7 \pm 1.5^{\mathrm{a}, \mathrm{A}}$ & $-0.6 \pm 0.7^{\mathrm{a}, \mathrm{A}}$ & $0.6 \pm 0.1$ \\
Rubber & $5.6 \pm 2.5^{\mathrm{a}, \mathrm{A}}$ & $-1.0 \pm 0.2^{\mathrm{a}, \mathrm{A}}$ & $0.5 \pm 0.2$ \\
Oil palm (smallholder plantation) & $11.5 \pm 2.9^{\mathrm{a}, \mathrm{A}}$ & $-0.2 \pm 1.2^{\mathrm{a}, \mathrm{A}}$ & $1.0 \pm 0.30 .2 \pm 0.0$ \\
\hline Loam Acrisol landscape & & & $0.9 \pm 0.2$ \\
\hline $\begin{array}{l}\text { Forest } \\
\text { Jungle rubber }\end{array}$ & $9.8 \pm 1.5^{\mathrm{a}, \mathrm{A}}$ & $1.9 \pm 1.3^{\mathrm{ab}}$ & $1.2 \pm 0.6$ \\
Rubber & $14.0 \pm 6.7^{\mathrm{a}, \mathrm{A}}$ & $5.7 \pm 5.8^{\mathrm{a}, \mathrm{A}}$ & $0.7 \pm 0.2$ \\
$\begin{array}{l}\text { Oil palm } \\
\text { (smallholder plantation) }\end{array}$ & $8.6 \pm 2.0^{\mathrm{a}, \mathrm{A}}$ & $-1.2 \pm 0.5^{\mathrm{b}, \mathrm{A}}$ & $1.1 \pm 0.50 .1 \pm 0.0$ \\
$\begin{array}{l}\text { Oil palm } \\
\text { (large-scale plantation) }\end{array}$ & $12.2 \pm 6.1^{\mathrm{a}, \mathrm{A}}$ & $0.7 \pm 0.7^{\mathrm{ab}, \mathrm{A}}$ & \\
\hline
\end{tabular}

soil $\mathrm{N}_{2} \mathrm{O}$ and $\mathrm{NO}$ fluxes following fertilizer application from smallholder oil palm plantations, we used the means of the three replicate trees per chamber location on each sampling day and conducted Pearson's correlation test for each site across the entire measurement period of fertilization effects $(n=6-11)$. To assess the spatial controls of soil biochemical characteristics (Appendix Table A2) on annual soil $\mathrm{N}_{2} \mathrm{O}$ fluxes, we used the annual flux of each replicate plot and conducted Spearman's rank correlation test separately for the reference land uses and converted land uses across landscapes $(n=16)$ and within each landscape $(n=8)$. We did not assess the spatial control of soil biochemical characteristics on annual soil NO fluxes since we did not calculate annual flux from the four measurement periods (as explained in Sect. 2.2). Correlations were considered statistically significant at $P \leq 0.05$ and marginally significant at $P \leq 0.09$. All statistical analyses were conducted using R 3.2.2 (R Development Core Team, 2015).

\section{Results}

\subsection{Soil N-oxide fluxes}

In the reference land uses (forest and jungle rubber), $\mathrm{N}_{2} \mathrm{O}$ was the dominant $\mathrm{N}$ oxide emitted from soils. In the clay Acrisol landscape, there was a net NO consumption in the soil of the jungle rubber (Table 1). Soil $\mathrm{N}_{2} \mathrm{O}$ and $\mathrm{NO}$ fluxes from reference land uses were comparable between the two landscapes $(P=0.54-0.74$; Table $1 ;$ Fig. $1 \mathrm{a}, \mathrm{b})$. These fluxes also exemplified high inherent spatial and temporal variations as indicated by their large standard errors.

In the converted land uses (smallholder rubber and oil palm plantations), soil $\mathrm{N}_{2} \mathrm{O}$ fluxes were similar to the fluxes of reference land uses $(P=0.58-0.76$; Table 1 ; Fig. $1 \mathrm{a}, \mathrm{b})$ within each landscape. However, in the loam Acrisol landscape, the large-scale oil palm plantation had on average 3.5 times higher soil $\mathrm{N}_{2} \mathrm{O}$ fluxes than those from the smallholder plantations (Table 1), although this trend was not statistically different $(P=0.15)$ because of the large variation among replicate plots (as indicated by the large standard error) in this large-scale plantation. Soil NO fluxes were not different either among land uses in the clay Acrisol landscape $(P=0.73$; Table 1$)$. However, in the loam Acrisol landscape, soil NO fluxes were marginally lower $(P=0.07)$ in rubber plantations (with net NO consumption in the soil) than in jungle rubber (with net NO emission), whereas they were intermediary in forests and oil palm plantations (Table 1).

\subsection{Fertilization effects on soil N-oxide fluxes from smallholder oil palm plantations}

In comparison to the unfertilized area (chamber location $\mathrm{NF}$ at $4-4.5 \mathrm{~m}$ from the tree base), soil $\mathrm{N}_{2} \mathrm{O}$ fluxes were 
Table 2. Mean ( \pm SE, $n=3$ oil palm trees) soil $\mathrm{N}_{2} \mathrm{O}$ and $\mathrm{NO}$ fluxes from three chamber locations during a fertilization in three (for $\mathrm{N}_{2} \mathrm{O}$ ) or one (for NO) smallholder oil palm plantations within each landscape, measured 6 to 11 times during the 3-8.5 weeks following fertilization. Means followed by different letters indicate significant differences among chamber locations within each site (linear mixed-effect models with Fisher's LSD test at $P \leq 0.05$ ). Chamber F1, F2 and NF were placed at $0.3 \mathrm{~m}$ (with incidental fertilization), $0.8 \mathrm{~m}$ (fertilized area) and 4-4.5 m (non-fertilized area, serving as the reference chamber), respectively, from the stem base. A total of $0.32 \mathrm{~kg} \mathrm{~N}^{-1} \mathrm{was}$ applied in the clay Acrisol and $0.26 \mathrm{~kg} \mathrm{~N} \mathrm{rre}^{-1}$ in the loam Acrisol in accordance to the smallholders' practices.

\begin{tabular}{|c|c|c|c|}
\hline Oil palm site & Chamber location & $\mathrm{N}_{2} \mathrm{O}$ fluxes $\left(\mu \mathrm{g} \mathrm{N} \mathrm{m}{ }^{-2} \mathrm{~h}^{-1}\right)$ & NO fluxes $\left(\mu \mathrm{g} \mathrm{N} \mathrm{m}{ }^{-2} \mathrm{~h}^{-1}\right)$ \\
\hline \multicolumn{4}{|c|}{ Clay Acrisol landscape } \\
\hline \multirow[t]{3}{*}{1} & $\mathrm{~F} 1$ & $156.7 \pm 86.8^{b}$ & - \\
\hline & $\mathrm{F} 2$ & $910.1 \pm 410.0^{\mathrm{a}}$ & - \\
\hline & $\mathrm{NF}$ & $6.9 \pm 3.3^{\mathrm{c}}$ & - \\
\hline \multirow[t]{3}{*}{2} & F1 & $130.6 \pm 34.6^{\mathrm{b}}$ & - \\
\hline & $\mathrm{F} 2$ & $692.7 \pm 144.1^{\mathrm{a}}$ & - \\
\hline & NF & $9.9 \pm 3.0^{\mathrm{c}}$ & - \\
\hline \multirow[t]{3}{*}{3} & $\mathrm{~F} 1$ & $45.5 \pm 3.7^{b}$ & $4.7 \pm 1.7^{b}$ \\
\hline & $\mathrm{F} 2$ & $1281.0 \pm 486.7^{\mathrm{a}}$ & $535.3 \pm 194.5^{\mathrm{a}}$ \\
\hline & NF & $1.1 \pm 1.6^{\mathrm{c}}$ & $1.5 \pm 1.5^{\mathrm{b}}$ \\
\hline Oil palm site & Chamber location & $\mathrm{N}_{2} \mathrm{O}$ fluxes $\left(\mu \mathrm{N} \mathrm{m}^{-2} \mathrm{~h}^{-1}\right)$ & NO fluxes $\left(\mu g \mathrm{~N} \mathrm{~m}^{-2} \mathrm{~h}^{-1}\right)$ \\
\hline \multicolumn{4}{|c|}{ Loam Acrisol landscape } \\
\hline \multirow[t]{3}{*}{1} & $\mathrm{~F} 1$ & $33.5 \pm 9.8^{\mathrm{b}}$ & - \\
\hline & $\mathrm{F} 2$ & $133.4 \pm 34.9^{\mathrm{a}}$ & - \\
\hline & $\mathrm{NF}$ & $11.8 \pm 6.1^{b}$ & - \\
\hline \multirow[t]{3}{*}{2} & $\mathrm{~F} 1$ & $129.7 \pm 46.2^{\mathrm{a}}$ & $46.2 \pm 19.6^{\mathrm{b}}$ \\
\hline & $\mathrm{F} 2$ & $205.3 \pm 24.2^{\mathrm{a}}$ & $157.1 \pm 35.7^{\mathrm{a}}$ \\
\hline & $\mathrm{NF}$ & $7.9 \pm 4.8^{\mathrm{b}}$ & $0.7 \pm 0.3^{\mathrm{b}}$ \\
\hline \multirow[t]{3}{*}{3} & $\mathrm{~F} 1$ & $5.2 \pm 1.0^{\mathrm{b}}$ & - \\
\hline & $\mathrm{F} 2$ & $104.5 \pm 81.9^{\mathrm{a}}$ & - \\
\hline & NF & $3.7 \pm 1.7^{b}$ & - \\
\hline
\end{tabular}

on average 442 times (clay Acrisol) and 22 times (loam Acrisol) higher within the small fertilized areas around the oil palms (chamber location F2 at $0.8-1 \mathrm{~m}$ from the tree base that received 0.32 and $0.26 \mathrm{~kg} \mathrm{~N}_{\text {tree }}{ }^{-1}$ in the clay and loam Acrisols, respectively) during the 3 to 8.5 weeks following fertilizer applications (all $P<0.01-0.03$; Table 2; Fig. 2c, d). In the chamber location closest to the tree (chamber location $\mathrm{F} 1$ at $0.3 \mathrm{~m}$ from the tree base), soil $\mathrm{N}_{2} \mathrm{O}$ emissions were also 25 times higher compared to the reference chamber location NF in the clay Acrisol landscape (all $P<0.01$; Table 2; Fig. 2a). In the loam Acrisol landscape, we only detected such an effect in site 2, which displayed 16 times higher soil $\mathrm{N}_{2} \mathrm{O}$ emissions in chamber location $\mathrm{F} 1$ compared to the reference chamber location NF $(P=0.03$; Table 2; Fig. 2b).

In the clay Acrisol landscape, soil $\mathrm{N}_{2} \mathrm{O}$ emissions in chamber location F2 increased immediately after fertilizer application, reached a peak within 9 days following fertilizer application and stayed elevated for at most 2 months (Fig. 2c). In the loam Acrisol landscape, $\mathrm{N}_{2} \mathrm{O}$ fluxes in chamber loca- tion F2 increased within the first 5 days, reached maximum fluxes within 5-21 days and remained elevated for at most 6.5 weeks (Fig. 2d). Soil $\mathrm{N}_{2} \mathrm{O}$ fluxes in chamber location $\mathrm{F} 1$ displayed a similar but less pronounced pattern to those of chamber location F2 in both landscapes (Fig. 2a, b).

The average contributions of the fertilizer-induced $\mathrm{N}_{2} \mathrm{O}$ emissions to the annual fluxes were $21 \%$ in the clay Acrisol landscape and only $6 \%$ in the loam Acrisol landscape (Table 1). To calculate this contribution (see Sect. 2.2), we considered the area coverage ( $4 \%$ of a hectare, based on the number of palms ha ${ }^{-1}$ ) and time span of fertilizer-induced $\mathrm{N}_{2} \mathrm{O}$ emissions.

Compared to the unfertilized area (chamber location NF), soil NO fluxes from the fertilized area (chamber location F2) had on average 357 times (clay Acrisol) and 238 times (loam Acrisol) higher fluxes (both $P<0.01$ ) during 6 to 8.5 weeks of measurements following fertilizer application (Table 2; Fig. 3c, d). No differences in soil NO fluxes were detected between chamber locations F1 and NF $(P=0.10-0.12$; Table 2; Fig. 3a, b). Soil NO fluxes in chamber location F2 

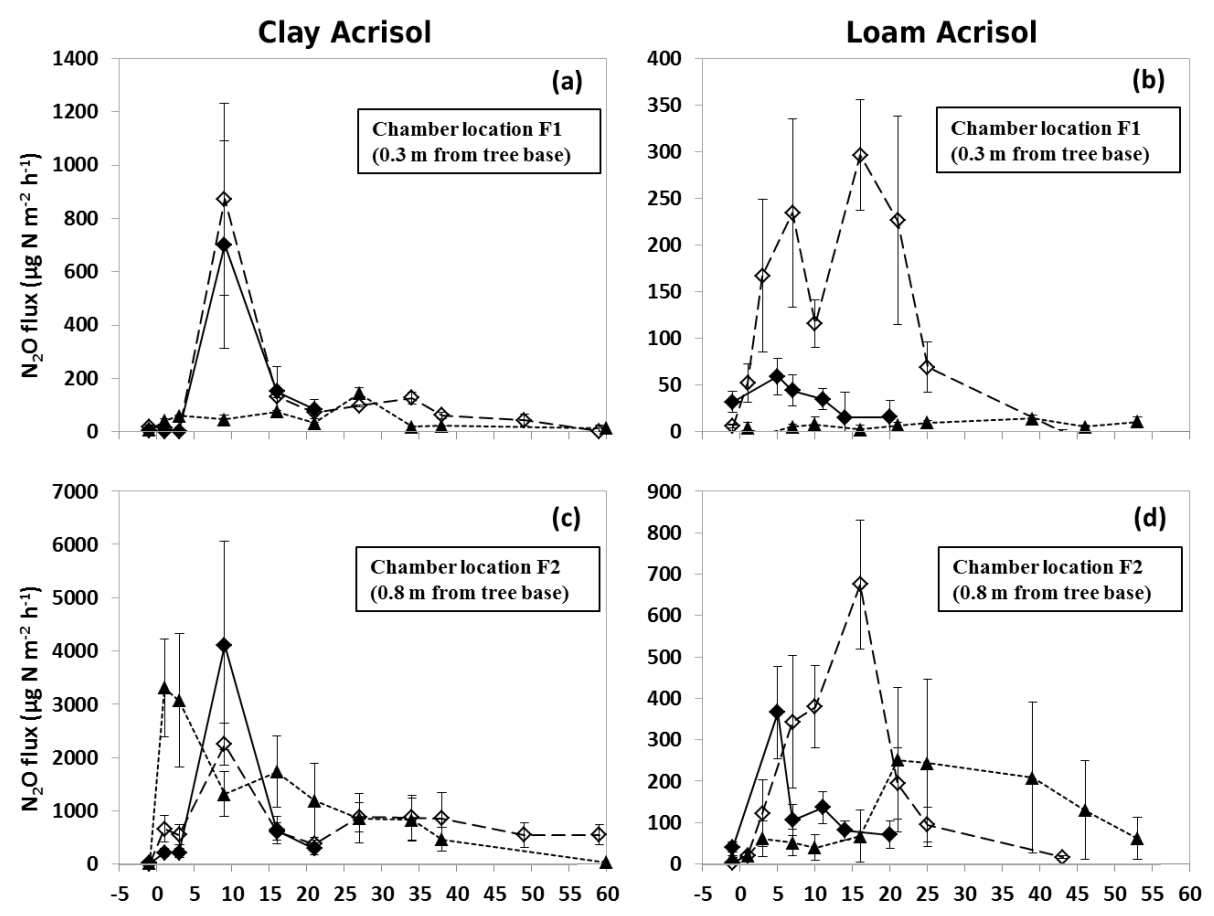

Days since fertilizer application

Figure 2. Mean ( $\pm \mathrm{SE}, n=3$ oil palm trees) soil $\mathrm{N}_{2} \mathrm{O}$ fluxes during a fertilization in smallholder oil palm plantations $1(\diamond), 2(\diamond)$ and 3 $(\mathbf{\Lambda})$ in the clay $(\mathbf{a}, \mathbf{c})$ and loam Acrisol $(\mathbf{b}, \mathbf{d})$ landscapes. Smallholders fertilized around the base of each tree at about $0.8-1 \mathrm{~m}$ from the tree base. Fluxes were measured at F1 $=0.3 \mathrm{~m}$ from the tree base $(\mathbf{a}, \mathbf{b})$ and at F2 $=0.8 \mathrm{~m}$ from the tree base on the fertilized location $(\mathbf{c}, \mathbf{d})$ with

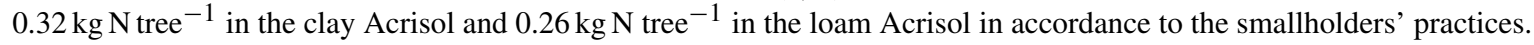

peaked after 10 days in the loam Acrisol and after 3 weeks in the clay Acrisol landscape (Fig. 3c, d) and returned to the background fluxes after 6-8.5 weeks, with a drastic drop after 3-5 weeks (Fig. 3c, d). In chamber location F1, soil NO fluxes increased quickly and decreased to the background fluxes within at most 16 days following fertilizer application (Fig. 3a, b). As was the case for the monthly sampling, soil $\mathrm{N}_{2} \mathrm{O}$ fluxes from chamber locations $\mathrm{F} 1$ and $\mathrm{F} 2$ were larger than soil NO fluxes for both landscapes (Table 2; Figs. 2a-d and 3a-d). Comparing between landscapes, soil $\mathrm{N}_{2} \mathrm{O}$ fluxes from chamber location F2 were higher in the clay than in the loam Acrisol soils ( $P=0.09$; Table 2; Fig. $2 \mathrm{c}, \mathrm{d})$ but were comparable for chamber location F1 $(P=0.41$; Table 2; Fig. 2a, b) and for soil NO fluxes of both chamber locations $(P=0.45-0.78$; Table 2; Fig. 3a-d).

Fertilizer-induced soil NO fluxes in the loam Acrisol landscape were $0.07 \pm 0.02 \mathrm{~kg} \mathrm{NO}-\mathrm{N} \mathrm{ha}^{-1} \mathrm{yr}^{-1}$, which was roughly the same as our extrapolated annual value of

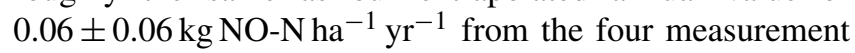
periods (Table 1). In the clay Acrisol landscape, fertilizer-

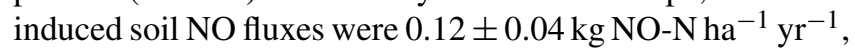
which was a net emission compared to our extrapolated annual value with a net sink of $-0.02 \pm 0.11 \mathrm{~kg} \mathrm{NO}$ $\mathrm{Nha}^{-1} \mathrm{yr}^{-1}$, based on the four measurement periods (Table 1). The percentages of combined soil $\mathrm{N}_{2} \mathrm{O}$ and $\mathrm{NO}$ fluxes to the applied $\mathrm{N}$-fertilizer rate were on average $0.73 \% \mathrm{yr}^{-1}$ in the clay Acrisol landscape and $0.20 \% \mathrm{yr}^{-1}$ in the loam Acrisol landscape.

\subsection{Temporal controls of soil $\mathbf{N}$-oxide fluxes}

In the reference land uses, soil $\mathrm{N}_{2} \mathrm{O}$ and $\mathrm{NO}$ fluxes were both positively correlated with soil $\mathrm{NO}_{3}^{-}$contents, while soil $\mathrm{NO}$ fluxes were also negatively correlated with WFPS and soil $\mathrm{NH}_{4}^{+}$contents (Table 3 ). In the converted land uses, soil $\mathrm{N}_{2} \mathrm{O}$ fluxes were positively correlated with soil $\mathrm{NO}_{3}^{-}$contents (Table 3). There were no significant correlations observed between soil NO fluxes and soil factors in the converted land uses due to the very low NO emissions and even net NO uptake.

From the fertilizer application experiment in the smallholder oil palm plantations, the location directly receiving fertilizer (chamber location F2) showed positive correlations of soil $\mathrm{N}_{2} \mathrm{O}$ fluxes with soil $\mathrm{NH}_{4}^{+}$and/or $\mathrm{NO}_{3}^{-}$contents in three of the six sites (Table 4). Here, soil NO fluxes also correlated positively with soil $\mathrm{NO}_{3}^{-}$contents in the loam Acrisol but not in the clay Acrisol (Table 4). In chamber location F1, positive correlations of soil $\mathrm{N}_{2} \mathrm{O}$ fluxes with soil $\mathrm{NH}_{4}^{+}$and/or $\mathrm{NO}_{3}^{-}$contents were observed in four of the six sites (Table 4). The correlations of soil $\mathrm{N}_{2} \mathrm{O}$ fluxes with mineral $\mathrm{N}$ for 

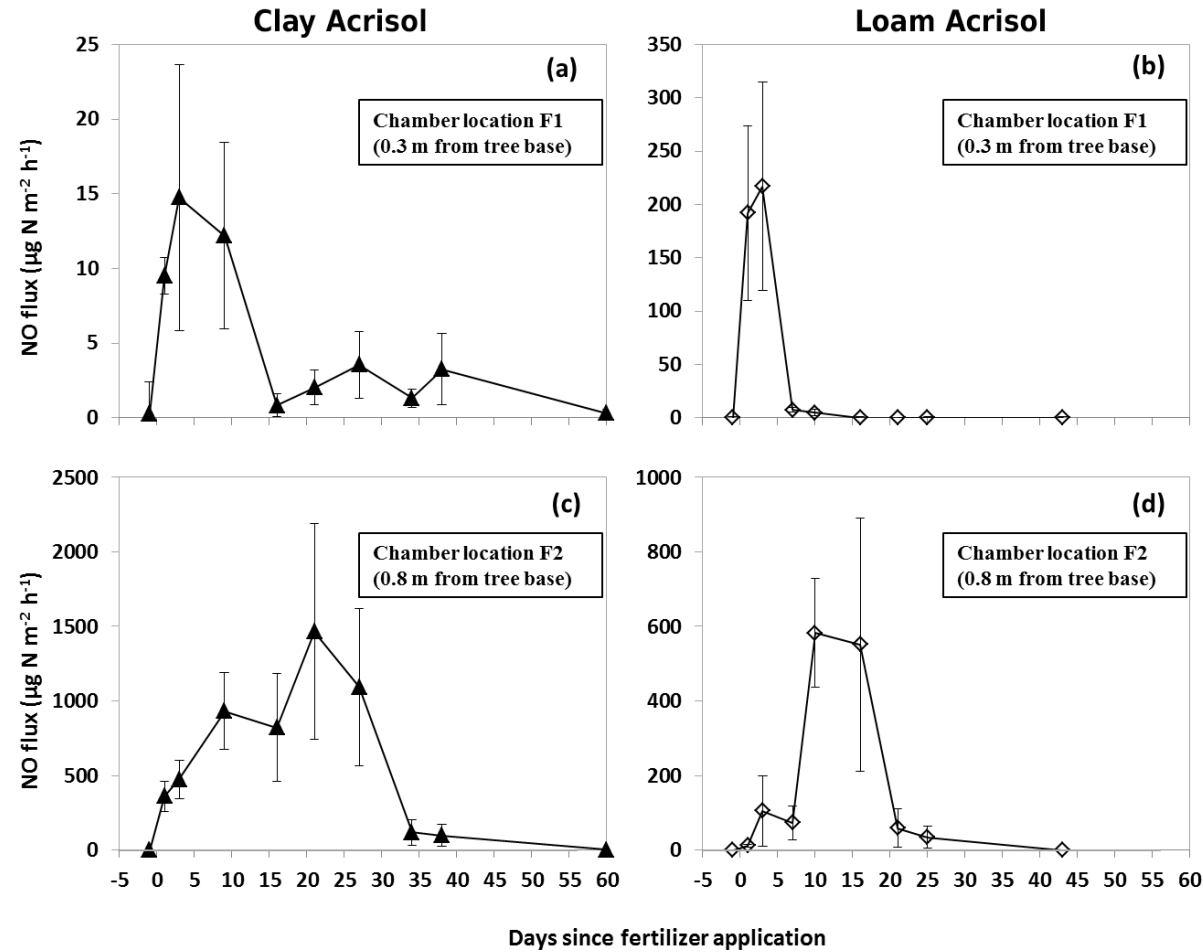

Figure 3. Mean ( $\pm \mathrm{SE}, n=3$ oil palm trees) soil NO fluxes during a fertilization in a smallholder oil palm plantation in the clay (a, c) and loam Acrisol (b, d) landscapes. Smallholders fertilized around the base of each tree at about $0.8-1 \mathrm{~m}$ from the tree base. Fluxes were measured at $\mathrm{F} 1=0.3 \mathrm{~m}$ from the tree base $(\mathbf{a}, \mathbf{b})$ and at $\mathrm{F} 2=0.8 \mathrm{~m}$ from the tree base on the fertilized location $(\mathbf{c}, \mathbf{d})$ with $0.32 \mathrm{~kg} \mathrm{~N}$ tree ${ }^{-1}$ in the clay Acrisol and $0.26 \mathrm{~kg} \mathrm{~N}$ tree $^{-1}$ in the loam Acrisol in accordance to the smallholders' practices.

Table 3. Pearson correlation coefficients between soil $\mathrm{N}_{2} \mathrm{O}$ flux $\left(n=48 ; \mu \mathrm{g} \mathrm{N} \mathrm{m}^{-2} \mathrm{~h}^{-1}\right)$, soil NO flux $\left(n=16 ; \mu \mathrm{g} \mathrm{N} \mathrm{m}{ }^{-2} \mathrm{~h}^{-1}\right)$, water-filled pore space (WFPS; \%, top $0.05 \mathrm{~m}$ depth), soil temperature $\left({ }^{\circ} \mathrm{C}\right.$, top $0.05 \mathrm{~m}$ depth) and extractable mineral N (mg N kg -1 , top $\left.0.05 \mathrm{~m} \mathrm{depth}\right)$ across landscapes for the reference and converted land uses. The correlation was conducted using the means of the four replicate plots per land use on each of the 12 monthly measurements (for soil $\mathrm{N}_{2} \mathrm{O}$ fluxes) and four monthly to bimonthly measurements (for soil $\mathrm{NO}$ fluxes).

\begin{tabular}{llrrrr}
\hline Land-use type & Variable & WFPS & Soil temp. & $\mathrm{NH}_{4}^{+}$ & $\mathrm{NO}_{3}^{-}$ \\
\hline Reference land uses (forest and jungle rubber) & Soil N2O flux & -0.21 & -0.09 & -0.23 & $0.38^{\mathrm{b}}$ \\
& Soil NO flux & $-0.74^{\mathrm{b}}$ & -0.15 & $-0.48^{\mathrm{a}}$ & $0.69^{\mathrm{b}}$ \\
\hline Converted land uses (rubber and oil palm) & Soil N $\mathrm{N}_{2} \mathrm{O}$ flux & 0.11 & 0.15 & 0.23 & $0.37^{\mathrm{b}}$ \\
& Soil NO flux & -0.05 & 0.09 & -0.05 & 0.23 \\
\hline
\end{tabular}

${ }^{\mathrm{a}} P \leq 0.09,{ }^{\mathrm{b}} P \leq 0.01$

chamber location F1 in site 2 of the clay Acrisol landscape were caused by one measurement period with very high flux, and exclusion of this observation resulted in a non-significant correlation. For soil NO fluxes from chamber location F1, we did not detect any significant correlation with soil factors (Table 4). A positive correlation of soil $\mathrm{N}_{2} \mathrm{O}$ fluxes with WFPS was observed for chamber locations F1 and F2 in site 1 of the loam Acrisol landscape, whereas this correlation was negative for chamber location F1 in site 3 of the same landscape (Table 4). We also detected a negative correlation between soil NO fluxes and WFPS for chamber location F2 in site 3 of the clay Acrisol, whereas in the same site soil NO fluxes and
WFPS were positively correlated for the unfertilized chamber location NF (Table 4); however, the latter correlation was caused by only one sampling time with a high flux and high WFPS.

\subsection{Spatial controls of annual soil $\mathrm{N}_{2} \mathrm{O}$ fluxes}

The soil physical and biochemical characteristics (reported earlier by Allen et al., 2015) that showed significant correlations with annual soil $\mathrm{N}_{2} \mathrm{O}$ fluxes are reported in Appendix Table A2. For the reference land uses, annual $\mathrm{N}_{2} \mathrm{O}$ fluxes were positively correlated with gross nitrification rates 
Table 4. Pearson correlation coefficients $\left(n=6-11\right.$ measurements following fertilization) between $\mathrm{N}$-oxide fluxes $\left(\mu \mathrm{g} \mathrm{N} \mathrm{m}{ }^{-2} \mathrm{~h}^{-1}\right)$, waterfilled pore space (WFPS; \%, top $0.05 \mathrm{~m}$ depth) and extractable mineral $\mathrm{N}\left(\mathrm{mg} \mathrm{N} \mathrm{kg}^{-1}\right.$, top $0.05 \mathrm{~m}$ depth), measured at different chamber locations (F1, F2 and NF were at $0.3 \mathrm{~m}$, with incidental fertilization; $0.8 \mathrm{~m}$, fertilized area; and 4-4.5 m, non-fertilized area; respectively, from the stem base). The correlation was conducted using the means of the three replicate trees per chamber location on each sampling day following fertilization.

\begin{tabular}{|c|c|c|c|c|c|}
\hline Oil palm plantation site & Chamber location & Variable & WFPS & $\mathrm{NH}_{4}^{+}$ & $\mathrm{NO}_{3}^{-}$ \\
\hline \multicolumn{6}{|l|}{ Clay Acrisol landscape } \\
\hline \multirow[t]{3}{*}{$1(n=6$ measurements $)$} & $\mathrm{F} 1$ & \multirow{3}{*}{ Soil $\mathrm{N}_{2} \mathrm{O}$ flux } & 0.55 & $0.88^{\mathrm{b}}$ & 0.46 \\
\hline & $\mathrm{F} 2$ & & 0.57 & -0.22 & -0.31 \\
\hline & NF & & 0.37 & -0.64 & -0.44 \\
\hline \multirow{3}{*}{2 ( $n=11$ measurements $)$} & F1 & \multirow{3}{*}{ Soil $\mathrm{N}_{2} \mathrm{O}$ flux } & 0.11 & $0.93^{\mathrm{c}}$ & $0.95^{\mathrm{c}}$ \\
\hline & $\mathrm{F} 2$ & & 0.08 & 0.05 & -0.06 \\
\hline & NF & & 0.09 & -0.44 & -0.45 \\
\hline \multirow[t]{3}{*}{3 ( $n=10$ measurements) } & $\mathrm{F} 1$ & \multirow[t]{3}{*}{ Soil $\mathrm{N}_{2} \mathrm{O}$ flux } & -0.19 & 0.10 & 0.09 \\
\hline & $\mathrm{F} 2$ & & 0.05 & $0.86^{\mathrm{c}}$ & $0.85^{\mathrm{c}}$ \\
\hline & NF & & -0.32 & 0.06 & -0.44 \\
\hline \multirow[t]{3}{*}{3 ( $n=10$ measurements) } & $\mathrm{F} 1$ & \multirow[t]{3}{*}{ Soil NO flux } & -0.34 & 0.44 & 0.48 \\
\hline & $\mathrm{F} 2$ & & $-0.61^{\mathrm{a}}$ & 0.10 & -0.04 \\
\hline & NF & & $0.59^{\mathrm{a}}$ & -0.14 & -0.13 \\
\hline \multicolumn{6}{|l|}{ Loam Acrisol landscape } \\
\hline \multirow[t]{3}{*}{1 ( $n=6$ measurements $)$} & $\mathrm{F} 1$ & \multirow{3}{*}{ Soil $\mathrm{N}_{2} \mathrm{O}$ flux } & $0.96^{\mathrm{c}}$ & -0.18 & 0.03 \\
\hline & $\mathrm{F} 2$ & & $0.78^{\mathrm{a}}$ & 0.61 & -0.40 \\
\hline & NF & & -0.06 & -0.29 & $<0.01$ \\
\hline \multirow[t]{3}{*}{2 ( $n=9$ measurements) } & $\mathrm{F} 1$ & \multirow{3}{*}{ Soil $\mathrm{N}_{2} \mathrm{O}$ flux } & -0.55 & $0.71^{\mathrm{b}}$ & -0.03 \\
\hline & $\mathrm{F} 2$ & & 0.35 & -0.20 & $0.89^{\mathrm{c}}$ \\
\hline & NF & & 0.34 & $<0.01$ & -0.35 \\
\hline \multirow[t]{3}{*}{3 ( $n=11$ measurements) } & $\mathrm{F} 1$ & \multirow[t]{3}{*}{ Soil $\mathrm{N}_{2} \mathrm{O}$ flux } & $-0.68^{b}$ & $0.67^{b}$ & $0.62^{b}$ \\
\hline & $\mathrm{F} 2$ & & -0.27 & -0.20 & $0.57^{\mathrm{a}}$ \\
\hline & NF & & 0.36 & 0.19 & 0.06 \\
\hline \multirow[t]{3}{*}{2 ( $n=9$ measurements) } & $\mathrm{F} 1$ & \multirow[t]{3}{*}{ Soil NO flux } & -0.07 & 0.18 & -0.27 \\
\hline & $\mathrm{F} 2$ & & 0.07 & -0.11 & $0.96^{\mathrm{c}}$ \\
\hline & NF & & -0.16 & 0.12 & -0.23 \\
\hline
\end{tabular}

${ }^{\mathrm{a}} P \leq 0.09,{ }^{\mathrm{b}} P \leq 0.05,{ }^{\mathrm{c}} P \leq 0.01$.

across landscapes (Spearman's $\rho=0.57, P=0.02, n=16$ ). Within each landscape, annual soil $\mathrm{N}_{2} \mathrm{O}$ fluxes from the reference land uses correlated negatively with soil $\mathrm{C}: \mathrm{N}$ ratio $(\rho=-0.69, P=0.07, n=8)$ in the clay Acrisol, whereas in the loam Acrisol annual soil $\mathrm{N}_{2} \mathrm{O}$ fluxes correlated positively with microbial C ( $\rho=0.69, P=0.07, n=8)$. For the converted land uses, annual $\mathrm{N}_{2} \mathrm{O}$ fluxes correlated negatively with sand content across landscapes $(\rho=-0.57, P=0.06$, $n=12$ ). There were no other correlations detected with any other soil biochemical parameters.

\section{Discussion}

\subsection{Soil $\mathrm{N}_{2} \mathrm{O}$ and $\mathrm{NO}$ fluxes from the reference land uses}

The $\mathrm{N}_{2} \mathrm{O}$ fluxes from our forest soils (Table 1) fell at the lower end of those reported for humid tropical forests (10-85 $\mu \mathrm{g} \mathrm{N}_{2} \mathrm{O}-\mathrm{N} \mathrm{m}^{-2} \mathrm{~h}^{-1}$; summarized by Castaldi et al., 2013). Compared to soil $\mathrm{N}_{2} \mathrm{O}$ fluxes measured in Indonesia, our values were comparable to those reported for montane forests on Cambisol soil with similar sampling frequency and spatial replication $\left(13 \mu \mathrm{g} \mathrm{N} \mathrm{N}_{2} \mathrm{O}-\mathrm{N} \mathrm{m}^{-2} \mathrm{~h}^{-1}\right.$; Purbopuspito et al., 2006) and to five lowland forest stands on Acrisol soil measured once $\left(12 \mu \mathrm{g} \mathrm{N}_{2} \mathrm{O}-\mathrm{N} \mathrm{m}^{-2} \mathrm{~h}^{-1}\right.$; Ishizuka et al., 2005). However, soil $\mathrm{N}_{2} \mathrm{O}$ fluxes from our forests were lower 
than those reported for montane forests on Cambisol soils with six monthly measurements and comparable replication (25 $\mu \mathrm{g} \mathrm{N} \mathrm{N}_{2} \mathrm{O}-\mathrm{N} \mathrm{m}^{-2} \mathrm{~h}^{-1}$; Veldkamp et al., 2008) and from a lowland forest on Ferralsol soil with 13 measurements at monthly intervals $\left(20 \mu \mathrm{g} \mathrm{N} \mathrm{N}_{2} \mathrm{O}-\mathrm{N} \mathrm{m}^{-2} \mathrm{~h}^{-1}\right.$; Aini et al., 2015). In contrast, our values were higher than those reported for two lowland forests on Ferralsol soil with nine measurements at monthly intervals ( $3 \mu \mathrm{g} \mathrm{N}_{2} \mathrm{O}-\mathrm{N} \mathrm{m}^{-2} \mathrm{~h}^{-1}$; Ishizuka et al., 2002). Since the studies from the montane forests were conducted on fertile, less weathered Cambisol soils and the studies within the same region (Jambi province) by Ishizuka et al. (2002, 2005) and Aini et al. (2015) have less sampling frequency or spatial replication, their values should be carefully related to our measured fluxes.

Soil NO fluxes from Southeast Asian lowland forests are not reported so far. Our measured NO fluxes from the forest soils (Table 1) tended to be lower than those reported for lowland forests in Latin America, with soils ranging from less weathered Cambisols to highly weathered Acrisols and Ferralsols (from 3-90 $\mu \mathrm{g}$ NO-N m${ }^{-2} \mathrm{~h}^{-1}$; Corre et al., 2014; Davidson et al., 2004; Keller et al., 2005; Verchot et al., 1999). There are only two studies conducted in Indonesia that reported soil NO fluxes from montane forests on Cambisol soils (Purbopuspito et al., 2006; Veldkamp et al., 2008). Our measured soil NO fluxes were comparable to the values reported for montane forests at $\geq 1800 \mathrm{~m}$ elevation $(2 \mu \mathrm{g}$ NO$\mathrm{N} \mathrm{m}^{-2} \mathrm{~h}^{-1}$; Purbopuspito et al., 2006) but lower than those reported for (pre)montane forests $\left(6-12 \mu \mathrm{g} \mathrm{NO}-\mathrm{N} \mathrm{m}^{-2} \mathrm{~h}^{-1}\right.$; Purbopuspito et al., 2006; Veldkamp et al., 2008). Although it is known that tropical forest soils are the largest natural source of $\mathrm{N}_{2} \mathrm{O}$ and produce considerable amounts of $\mathrm{NO}$, our measurements from these lowland forests in Jambi, Indonesia, on highly weathered Acrisol soils showed generally low soil N-oxide fluxes.

In contrast to our first hypothesis, soil $\mathrm{N}$-oxide fluxes from the reference land uses were comparable between loam and clay Acrisol landscapes. This is possibly due to the generally low soil $\mathrm{N}$ availability in these sites, as indicated by their lower gross $\mathrm{N}$ mineralization rates (Allen et al., 2015) compared, for example, to the less weathered Cambisol and $\mathrm{Ni}$ tisol soils in a lowland forest of Panama (Corre et al., 2010). Soil N-oxide fluxes are largely controlled, first, by the magnitude of soil $\mathrm{N}$ availability, as depicted in the HIP conceptual model (Davidson et al., 2000). This influence of soil $\mathrm{N}$ availability on $\mathrm{N}$-oxide fluxes was illustrated by the positive correlations of soil $\mathrm{N}$-oxide fluxes with soil $\mathrm{NO}_{3}^{-}$contents (Table 3). Across landscapes, this first level of control was also corroborated by the positive correlations of annual soil $\mathrm{N}_{2} \mathrm{O}$ fluxes with gross nitrification rates and within each landscape by the negative correlation with the soil $\mathrm{C}: \mathrm{N}$ ratio (clay Acrisol landscape) and by the positive correlation with microbial C (loam Acrisol landscape; see Sect. 3.4). Our findings were consistent with those from other tropical soils, illustrating that soil $\mathrm{N}$-oxide fluxes across or within sites are controlled by soil $\mathrm{N}$ availability as expressed in various in- dexes such as soil $\mathrm{NO}_{3}^{-}$contents (Keller and Reiners, 1994; Müller et al., 2015), nitrification rates (Davidson et al., 2000) and the soil $\mathrm{C}: \mathrm{N}$ ratio (Breuer et al., 2000).

Moreover, we attributed the low soil NO fluxes and the dominance of $\mathrm{N}_{2} \mathrm{O}$ (Table 1) in our sites to the second level of control of N-oxide fluxes - soil aeration status (HIP model; Davidson et al., 2000). The ratio of $\mathrm{N}_{2} \mathrm{O}$ to $\mathrm{NO}$ is expected to increase when WFPS exceeds $60 \%$ as low soil aeration favors $\mathrm{N}_{2} \mathrm{O}$ production by denitrification and nitrification processes (Davidson et al., 2000). WFPS in the reference land uses were $\geq 60 \%$ (Appendix Table A3, except in jungle rubber of the loam Acrisol with $54 \%$ WFPS). Hence, it was not surprising that our measured soil NO fluxes were close to zero or showed net consumption (Table 1); the high WFPS may have led to $\mathrm{NO}$ reduction to $\mathrm{N}_{2} \mathrm{O}$ (Conrad, 1996; Pilegaard, 2013). This was supported by the negative correlation between soil NO fluxes and WFPS (Table 3). Furthermore, increased concentrations of NO in the atmosphere due to biomass burning in this region (Field et al., 2009; Levine, 1999), which also occurred in 2013 (Gaveau et al., 2014), may have resulted in a net NO consumption (not only in the reference land uses but also in the converted land uses; Table 1) since increased ambient NO concentration could have enhanced soil NO uptake (Conrad, 1994). In summary, soil NO fluxes from the reference land uses were of minor importance compared to soil $\mathrm{N}_{2} \mathrm{O}$ fluxes. However, if droughts were to occur more frequently or extremely in this region (Lestari et al., 2014), soil NO fluxes might become important.

\subsection{Land-use change effects on soil $\mathrm{N}_{2} \mathrm{O}$ and $\mathrm{NO}$ fluxes}

Soil $\mathrm{N}_{2} \mathrm{O}$ fluxes from our unfertilized rubber plantations (Table 1) were comparable to a rubber plantation on Ferralsol soil in Malaysia with eight measurements during a 1.5-year period $\left(8 \mu \mathrm{g} \mathrm{N}_{2} \mathrm{O}-\mathrm{N} \mathrm{m}^{-2} \mathrm{~h}^{-1}\right.$, fertilized with $9 \mathrm{~kg} \mathrm{Nha}^{-1} \mathrm{yr}^{-1}$; Yashiro et al., 2008) and slightly higher than fluxes reported from a rubber plantation on a lateritic soil in China with only two months of measurement $\left(4 \mu \mathrm{g} \mathrm{N}_{2} \mathrm{O}-\mathrm{N} \mathrm{m}^{-2} \mathrm{~h}^{-1}\right.$, fertilized with $55 \mathrm{~kg} \mathrm{Nha}^{-1} \mathrm{yr}^{-1}$; Werner et al., 2006). Studies from the same region (Jambi, Indonesia) report either lower soil $\mathrm{N}_{2} \mathrm{O}$ fluxes from a rubber plantation on Ferralsol soil with 9 sampling days at monthly intervals ( $1 \mu \mathrm{g} \mathrm{N}_{2} \mathrm{O}-\mathrm{N} \mathrm{m}^{-2} \mathrm{~h}^{-1}$; Ishizuka et al., 2002) or higher fluxes from five rubber plantations on Acrisol soils with only a one-time measurement $\left(21 \mu \mathrm{g} \mathrm{N}_{2} \mathrm{O}-\mathrm{N} \mathrm{m}^{-2} \mathrm{~h}^{-1}\right.$; Ishizuka et al., 2005) and from one rubber plantation on Ferralsol soil with 13 sampling days at monthly intervals (12 $\mu \mathrm{g} \mathrm{N}_{2} \mathrm{O}-\mathrm{N} \mathrm{m}^{-2} \mathrm{~h}^{-1}$; Aini et al., 2015). The rubber plantations in these latter three studies were all unfertilized. Soil $\mathrm{N}_{2} \mathrm{O}$ fluxes from our oil palm plantations (Table 1), which had fertilization of $48-88 \mathrm{~kg} \mathrm{Nha}^{-1} \mathrm{yr}^{-1}$, were in the same order of magnitude as those reported from three fertilized oil palm plantations on Acrisol soils in Jambi, Indonesia, with only a one-time measurement $\left(15 \mu \mathrm{g} \mathrm{N} \mathrm{N}_{2} \mathrm{O}-\mathrm{N} \mathrm{m}^{-2} \mathrm{~h}^{-1}\right.$; 
Ishizuka et al., 2005) and from one unfertilized oil palm plantation on Cambisol soil in Jambi, Indonesia, with 13 monthly measurements (12 $\mu \mathrm{g} \mathrm{N}_{2} \mathrm{O}-\mathrm{N} \mathrm{m}^{-2} \mathrm{~h}^{-1}$; Aini et al., 2015). However, soil $\mathrm{N}_{2} \mathrm{O}$ fluxes from our oil palm sites were higher compared to one oil palm plantation on Ferralsol soil in Malaysia with eight measurements during a 1.5 -year period $\left(-0.1 \mu \mathrm{g} \mathrm{N} \mathrm{O}_{2} \mathrm{O} \mathrm{N} \mathrm{m}^{-2} \mathrm{~h}^{-1}\right.$, fertilized with $25 \mathrm{~kg} \mathrm{~N} \mathrm{ha}^{-1} \mathrm{yr}^{-1}$; Yashiro et al., 2008). Soil NO fluxes have never been reported from rubber or oil palm plantations.

In contrast to our second hypothesis, soil $\mathrm{N}$-oxide fluxes were comparable among land uses (except for soil NO fluxes between rubber and jungle rubber in the loam Acrisol landscape as discussed below), even with the observed decreases in soil mineral $\mathrm{N}$ levels among land uses (i.e., generally lower $\mathrm{NH}_{4}^{+}$and $\mathrm{NO}_{3}^{-}$levels in rubber plantations than in the reference land uses at both landscapes; Appendix Table A3). In the same study sites, Allen et al. (2015) found differences in other indices of soil $\mathrm{N}$ availability with landuse change, particularly in the clay Acrisol landscape: microbial $\mathrm{C}$ and $\mathrm{N}$, gross $\mathrm{N}$ mineralization and $\mathrm{NH}_{4}^{+}$immobilization rates decrease with conversion of forest to rubber or oil palm plantations. $\mathrm{N}$-oxide emissions generally account for only a small fraction of soil available $\mathrm{N}$ (e.g., $\mathrm{N}_{2} \mathrm{O}+$ $\mathrm{NO}$ emissions comprise $0.03 \%$ of gross $\mathrm{N}$ mineralization rates in a lowland forest on Cambisol and Nitisols soils in Panama; Corre et al., 2014). In our present study, the reference land uses on highly weathered Acrisol soils have low soil $\mathrm{N}$ availability, and their conversion to these plantations further decreases the soil N-cycling rates (Allen et al., 2015). Hence, we reason that we did not detect differences in $\mathrm{N}$ oxide fluxes with land-use conversion to rubber and oil palm plantations because we started with low soil $\mathrm{N}$ availability and low $\mathrm{N}$-oxide emissions and any changes were probably too small to detect statistically. The temporal pattern of soil $\mathrm{N}_{2} \mathrm{O}$ fluxes in the converted land uses were also controlled by soil $\mathrm{NO}_{3}^{-}$contents (Table 3 ), emphasizing the first level of control of soil $\mathrm{N}$ availability on soil $\mathrm{N}_{2} \mathrm{O}$ fluxes (HIP model; Davidson et al., 2000). Across landscapes, the correlations of annual soil $\mathrm{N}_{2} \mathrm{O}$ fluxes from these converted land uses with sand contents (see Sect. 3.4) also suggested the indirect influence of soil texture on water holding capacity, or conversely soil aeration status, which is the second level of control on soil $\mathrm{N}_{2} \mathrm{O}$ fluxes (HIP model). Consequently, the soil $\mathrm{N}$-oxide emission footprint of smallholder oil palm and rubber plantations was similar to the original land uses (Table 1). This finding was in contrast to a study by Hewitt et al. (2009) conducted in Sabah, Malaysian Borneo, wherein they showed that oil palm plantations emit more $\mathrm{N}$ oxides than rainforests, which may be explained by their higher fertilization rate $\left(500 \mathrm{~kg} \mathrm{Nha}^{-1} \mathrm{yr}^{-1}\right)$ compared to our smallholder oil palm plantations (48-88 $\mathrm{kg} \mathrm{N} \mathrm{ha}^{-1} \mathrm{yr}^{-1}$ ). Thus, an increase in fertilizer usage, e.g., in large-scale plantations in our study region, might change this soil $\mathrm{N}$-oxide emission footprint drawn mainly from smallholder plantations (see Sect. 4.3).
The lower soil NO fluxes in rubber compared to jungle rubber in the loam Acrisol (Table 1) partly supports our second hypothesis. These differences might be related to the high soil $\mathrm{NO}_{3}^{-}$contents and low WFPS in jungle rubber (Appendix Table A3), which could favor its relatively high soil NO emissions; this was also supported by the opposing correlations of soil NO flux with soil $\mathrm{NO}_{3}^{-}$and WFPS (Table 3). Additionally, the low soil NO fluxes from rubber plantations could be the result of the effect of monoterpenes, produced by rubber trees, which reduce nitrification in soil (Wang et al., 2007; White, 1991). This is supported by low gross nitrification rates (measured in the same plots by Allen et al., 2015), low soil $\mathrm{NO}_{3}^{-}$contents (Appendix Table A3) and consequently low soil NO fluxes in rubber plantations (Table 1).

\subsection{Soil management effects on soil $\mathrm{N}_{2} \mathrm{O}$ and $\mathrm{NO}$ fluxes from oil palm plantations}

$\mathrm{N}$-fertilizer application, a commonly employed soil management in oil palm plantations (e.g., Allen et al., 2015; Hassler et al., 2015), increases $\mathrm{N}$-oxide emission for a relatively short period (e.g., Koehler et al., 2009). Our findings show that these fertilizer-induced $\mathrm{N}$-oxide emissions were mainly limited to the small area around the palm base where fertilizer was commonly applied (4\% of the area in a hectare) and that $\mathrm{N}$-oxide emissions peaked within 3 weeks (Figs. 2 and 3). These $\mathrm{N}$-fertilizer-induced $\mathrm{N}_{2} \mathrm{O}$ fluxes of $6-21 \%$ of the annual soil $\mathrm{N}_{2} \mathrm{O}$ fluxes were similar in magnitude to the standard errors of the annual fluxes (estimated from the monthly measurements; Table 1). Thus, inclusion of these $\mathrm{N}$-induced emissions in our annual estimates did not result in statistically significant effects of land-use change.

The percentages of soil $\mathrm{N}_{2} \mathrm{O}$ and $\mathrm{NO}$ fluxes to the applied $\mathrm{N}$-fertilizer rate were smaller than those reported from other agricultural land uses in humid tropical regions (6.4-8.6\%; Veldkamp and Keller, 1997; Veldkamp et al., 1998). Usually the percentage of soil $\mathrm{N}$-oxide emissions to applied $\mathrm{N}$ fertilizer rate increases with increasing $\mathrm{N}$ fertilization rates (Hoben et al., 2011; Pennock and Corre, 2001). Since the fertilization rates in our studied smallholder oil palm plantations (48-88 $\mathrm{kg} \mathrm{N} \mathrm{ha}^{-1} \mathrm{yr}^{-1}$ ) were lower compared to the fertilization rates in these other studies $\left(300-360 \mathrm{~kg} \mathrm{~N} \mathrm{ha}^{-1} \mathrm{yr}^{-1}\right.$; Veldkamp and Keller, 1997; Veldkamp et al., 1998), our quantified $\mathrm{N}$-oxide loss from the $\mathrm{N}$ fertilizer were also low. The relatively high soil $\mathrm{N}_{2} \mathrm{O}$ fluxes from the large-scale oil palm plantation, although not statistically different from the smallholder plantations (Table 1), could be attributed to its high $\mathrm{N}$ fertilization rate $\left(196 \mathrm{~kg} \mathrm{~N} \mathrm{ha}^{-1} \mathrm{yr}^{-1}\right)$. Summing the fertilizer-induced $\mathrm{N}$-oxide fluxes and the annual soil $\mathrm{N}$-oxide emissions based on the monthly measurements (Table 1), these values from the smallholder plantations were low relative to the annual flux from the large-scale plantation (Table 1). Based on our finding that soil $\mathrm{N}_{2} \mathrm{O}$ fluxes following fertilizer application (chamber location F2) were higher in the clay than in the loam Acrisol landscapes (most likely 
due to higher WFPS in the clay, $61 \pm 8 \%$, than in the loam Acrisol, $27 \pm 3 \%$, during this measurement period), soil Noxide fluxes from large-scale plantations on clay soils could be even higher than what we measured here from a largescale plantation on a loam soil. Our findings reinforced the need to quantify these climate-relevant $\mathrm{N}$-oxide gases in large-scale plantations, which constitute $\sim 50 \%$ of the land area under oil palm plantation in all of Sumatra (BPS, 2014).

Temporal patterns of soil $\mathrm{N}$-oxide fluxes following fertilizer application were also controlled by soil $\mathrm{N}$ availability, as reflected by their positive correlations with soil $\mathrm{NH}_{4}^{+}$ and/or $\mathrm{NO}_{3}^{-}$contents (Table 4). The application of $\mathrm{N}$ fertilizer provides a temporary surplus of mineral $\mathrm{N}$ that was lost via gaseous emission and leaching (Kurniawan, 2016), and such effect diminished with time as the mineral $\mathrm{N}$ is incorporated into the soil $\mathrm{N}$-cycling processes (Allen et al., 2015). The positive correlation between soil $\mathrm{N}_{2} \mathrm{O}$ fluxes and WFPS (i.e., chamber locations F1 and F2 in site 1 of the loam Acrisol; Table 4) and the negative correlation between soil NO fluxes and WFPS (i.e., chamber location F2 in site 3 of the clay Acrisol landscape; Table 4) again attested that when the first level of control (soil $\mathrm{N}$ availability) was favorable (i.e., high soil mineral $\mathrm{N}$ contents in these fertilized chamber locations), the control of soil moisture on aeration status was enhanced, as such correlation was not seen in the unfertilized area (chamber location NF) or in the monthly measured fluxes (Tables 3 and 4). These correlations indicated that following fertilizer application soil NO fluxes decreased, whereas soil $\mathrm{N}_{2} \mathrm{O}$ fluxes increased with an increase in WFPS. In site 3 of the loam Acrisol, the seemingly contradicting negative correlation of soil $\mathrm{N}_{2} \mathrm{O}$ fluxes with WFPS (Table 4) was due to a decreasing WFPS following fertilizer application with concurrently increasing soil mineral $\mathrm{N}$ contents, with the latter dominantly driving the increases in soil $\mathrm{N}_{2} \mathrm{O}$ fluxes (i.e., positive correlations with $\mathrm{NH}_{4}^{+}$and $\mathrm{NO}_{3}^{-}$; Table 4). In summary, the short-term effect of fertilization also depicted the two levels of controls on soil $\mathrm{N}$-oxide fluxes as exemplified in the HIP model.

\section{Conclusions}

Our study provides the first spatially replicated study with a full year of measurements (at monthly interval) of soil $\mathrm{N}_{2} \mathrm{O}$ fluxes and the first reported soil NO fluxes from this region of hotspots of land-use conversion for globally important tree cash crops. In contrast to our first hypothesis, soil texture, through its role on soil fertility, did not directly affect soil $\mathrm{N}$-oxide fluxes (as shown by the comparable fluxes between landscapes with soil textural differences) but indirectly influenced the landscape-scale pattern of annual soil $\mathrm{N}_{2} \mathrm{O}$ fluxes in the converted land uses (i.e., negative correlation between annual $\mathrm{N}_{2} \mathrm{O}$ fluxes and sand content), most likely through its role on soil moisture availability. The generally low soil $\mathrm{N}$-oxide fluxes from the reference land uses were due to the low soil $\mathrm{N}$ availability in these highly weathered Acrisol soils (Allen et al., 2015). Forest or jungle rubber conversion to rubber and oil palm by smallholders also did not show significant changes in soil N-oxide fluxes, except for the decrease in soil NO fluxes in rubber plantations and for the short-term pulse of soil N-oxide fluxes following fertilizer application in oil palm plantations. These partly support our second hypothesis. Using a conservative estimate of $\mathrm{N}$-oxide $\left(\mathrm{N}_{2} \mathrm{O}+\mathrm{NO}\right)$ loss from the applied $\mathrm{N}$ fertilizer in oil palm plantations (average of $0.5 \%$ from the loam and clay Acrisol landscapes) and a conservative average $\mathrm{N}$ fertilization rate across smallholder and large-scale plantations of $100 \mathrm{~kg} \mathrm{~N} \mathrm{ha}^{-1} \mathrm{yr}^{-1}$, with a total land area of oil palm in Jambi province of 721000 ha (BPS, 2014), we estimated an annual soil $\mathrm{N}$-oxide emission from $\mathrm{N}$ fertilization of $361 \mathrm{t} \mathrm{N} \mathrm{yr}^{-1}$. The $\mathrm{N}$ fertilization rates in our smallholder oil palm plantations were only about one-fourth to one-half of what is commonly practiced in large-scale industrial plantations (e.g., $130-260 \mathrm{~kg} \mathrm{~N} \mathrm{ha}^{-1} \mathrm{yr}^{-1}$ in Jambi, Indonesia; Pahan, 2010), and our measurements from a large-scale oil palm plantation showed relatively high soil $\mathrm{N}$-oxide fluxes. To improve the estimate of soil $\mathrm{N}$-oxide fluxes at the regional level, future studies should focus on large-scale plantations (which constitute $38 \%$ of oil palm land area in Jambi province; BPS, 2014), with frequent measurements during the 2 months following the fertilizer application and particularly during the wet season for $\mathrm{N}_{2} \mathrm{O}$ flux measurements and during the dry season for NO flux measurements.

Data availability. The underlying research data of this study are deposited at the EFForTS-IS data repository (https://efforts-is. uni-goettingen.de), an internal data exchange-platform, which is accessible to all members of the Collaborative Research Center (CRC) 990 (see Acknowledgements). Based on the data sharing agreement within the CRC 990, these data are currently not publicly accessible but will be made available through a written request to the senior authors. 


\section{Appendix A: Detailed description of the linear mixed-effect models application}

For analysis of differences in N-oxide fluxes among land uses or between soil landscapes, we used the means of the four chambers representing each replicate plot on a sampling day. Linear mixed-effect (LME) models (Crawley, 2007) were used to assess differences between landscapes for the reference land uses (testing H1) or differences among land uses within each landscape (testing H2). In the LME models, either landscape or land use was considered as a fixed effect, whereas replicate plots and sampling days were considered as random effects. For comparison of soil $\mathrm{N}_{2} \mathrm{O}$ fluxes between the large-scale (PTPN VI) and smallholder oil palm plantations within the loam Acrisol landscape, we also used the means of the three chambers per replicate plot on each sampling day in the PTPN VI site, as there were no significant differences between these chamber locations (based on LME models with chamber location as a fixed effect and replicates as well as sampling days as random effects; $P=0.70)$. We then used the LME model with plantation ty- pes (i.e., large scale vs. smallholder) as a fixed effect and replicates and sampling days as random effects. For analysis of fertilization (i.e., as represented by the chamber locations F1, F2 and NF) on soil N-oxide fluxes from smallholder oil palm plantations, this was conducted for each site with oil palm trees as replicates. In the LME model for this experiment, chamber location was the fixed effect, whereas replicate palm trees and sampling days were the random effects. To assess differences in $\mathrm{N}$-oxide fluxes between landscapes following fertilization for chamber locations F1 and F2, we also used LME models with landscape as a fixed effect and with replicate plots (for $\mathrm{N}_{2} \mathrm{O}$ ) or replicate palm trees (for $\mathrm{NO}$ ) and sampling days as random effects. In all LME models, we included (1) a variance function that allows different variances of the fixed effect and/or (2) a first-order temporal autoregressive function to account for decreasing correlation between sampling days with increasing time difference, if these functions improved the relative goodness of the model fit based on the Akaike information criterion.

Table A1. Location and year of measurement.

\begin{tabular}{|c|c|c|c|}
\hline Measurement & Sampling location & N-oxide determined & Measurement year \\
\hline \multicolumn{4}{|l|}{ Clay Acrisol landscape } \\
\hline Four land uses (forest, jungle rubber, rubber, oil palm) & all 16 replicate plots & $\mathrm{N}_{2} \mathrm{O}$ and $\mathrm{NO}$ & 2013 \\
\hline Intensive measurements following fertilization (oil palm) & three oil palm replicate plots & $\mathrm{N}_{2} \mathrm{O}$ & 2013-2014 \\
\hline Intensive measurements following fertilization (oil palm) & one oil palm replicate plot & $\mathrm{NO}$ & 2013 \\
\hline \multicolumn{4}{|l|}{ Loam Acrisol landscape } \\
\hline Four land uses (forest, jungle rubber, rubber, oil palm) & all 16 replicate plots & $\mathrm{N}_{2} \mathrm{O}$ and $\mathrm{NO}$ & 2013 \\
\hline Intensive measurements following fertilization (oil palm) & three oil palm replicate plots & $\mathrm{N}_{2} \mathrm{O}$ & 2013-2014 \\
\hline Intensive measurements following fertilization (oil palm) & one oil palm replicate plot & NO & 2013 \\
\hline Large-scale oil palm plantation & PTPN VI & $\mathrm{N}_{2} \mathrm{O}$ & 2014-2015 \\
\hline
\end{tabular}


Table A2. Mean ( \pm SE, $n=4$ sites) soil physical and biochemical characteristics in the top $0.10 \mathrm{~m}$ depth (except sand content with $n=3$ sites) from different land uses within each landscape in Jambi, Sumatra, Indonesia. These soil factors and the gross nitrification rates were reported by Allen et al. (2015).

\begin{tabular}{|c|c|c|c|c|}
\hline \multirow[t]{2}{*}{ Soil characteristics } & \multicolumn{4}{|c|}{ Land-use type } \\
\hline & Forest & Jungle rubber & Rubber & Oil palm \\
\hline \multicolumn{5}{|l|}{ Clay Acrisol landscape } \\
\hline Sand $(\%)$ & $36 \pm 11$ & $27 \pm 20$ & $35 \pm 7$ & $11 \pm 2$ \\
\hline Soil $\mathrm{C}: \mathrm{N}$ ratio & $13.1 \pm 1.3$ & $13.0 \pm 0.3$ & $14.3 \pm 0.6$ & $13.5 \pm 0.2$ \\
\hline Microbial C $\left(\mathrm{mg} \mathrm{C} \mathrm{kg}^{-1}\right)$ & $1048 \pm 20$ & $922 \pm 223$ & $561 \pm 61$ & $617 \pm 112$ \\
\hline Gross nitrification rate $\left(\mathrm{mg} \mathrm{N} \mathrm{kg}^{-1} \mathrm{day}^{-1}\right)$ & $0.9 \pm 0.3$ & $1.0 \pm 0.2$ & $0.7 \pm 0.2$ & $2.0 \pm 0.8$ \\
\hline \multicolumn{5}{|l|}{ Loam Acrisol landscape } \\
\hline Sand $(\%)$ & $39 \pm 8$ & $42 \pm 19$ & $26 \pm 13$ & $43 \pm 14$ \\
\hline Soil $\mathrm{C}: \mathrm{N}$ ratio & $14.3 \pm 0.2$ & $13.7 \pm 0.8$ & $11.7 \pm 0.7$ & $12.5 \pm 0.5$ \\
\hline Microbial C $\left(\mathrm{mg} \mathrm{C} \mathrm{kg}^{-1}\right)$ & $514 \pm 48$ & $578 \pm 45$ & $461 \pm 58$ & $403 \pm 24$ \\
\hline Gross nitrification rate $\left(\mathrm{mg} \mathrm{N} \mathrm{kg}^{-1} \mathrm{day}^{-1}\right)$ & $1.9 \pm 0.4$ & $0.9 \pm 0.2$ & $0.9 \pm 0.2$ & $1.2 \pm 0.5$ \\
\hline
\end{tabular}

Table A3. Mean ( \pm SE, $n=4$ sites) soil water-filled pore space (WFPS) and extractable mineral $\mathrm{N}$ in the top $0.05 \mathrm{~m}$ depth for different land uses within each landscape in Jambi, Sumatra, Indonesia. Means followed by different lowercase letters indicate significant differences among land uses within each landscape and different capital letters indicate significant differences between landscapes within each land use (linear mixed-effect models with Fisher's LSD test at $P \leq 0.05$ ). These soil factors were reported by Hassler et al. (2015).

\begin{tabular}{lrrr}
\hline Land-use type & $\begin{array}{r}\text { WFPS } \\
(\%)\end{array}$ & $\begin{array}{r}\mathrm{NH}_{4}^{+} \\
\left(\mathrm{mg} \mathrm{N} \mathrm{kg}^{-1}\right)\end{array}$ & $\begin{array}{r}\mathrm{NO}_{3}^{-} \\
\left(\mathrm{mg} \mathrm{N} \mathrm{kg}^{-1}\right)\end{array}$ \\
\hline \multicolumn{3}{l}{ Clay Acrisol landscape } & \\
\hline Forest & $73.0 \pm 12.3^{\mathrm{a}, \mathrm{A}}$ & $7.0 \pm 1.0^{\mathrm{a}, \mathrm{A}}$ & $2.2 \pm 0.4^{\mathrm{a}, \mathrm{A}}$ \\
Jungle rubber & $86.7 \pm 5.9^{\mathrm{a}, \mathrm{A}}$ & $7.3 \pm 0.2^{\mathrm{a}, \mathrm{A}}$ & $0.2 \pm 0.1^{\mathrm{b}, \mathrm{B}}$ \\
Rubber & $61.5 \pm 7.4^{\mathrm{a}, \mathrm{A}}$ & $4.3 \pm 0.2^{\mathrm{b}, \mathrm{A}}$ & $0.1 \pm 0.0^{\mathrm{b}, \mathrm{B}}$ \\
Oil palm & $74.0 \pm 7.3^{\mathrm{a}, \mathrm{A}}$ & $5.8 \pm 0.6^{\mathrm{a}, \mathrm{A}}$ & $0.8 \pm 0.5^{\mathrm{b}, \mathrm{A}}$ \\
\hline Loam Acrisol landscape & & \\
\hline Forest & $64.0 \pm 3.3^{\mathrm{a}, \mathrm{A}}$ & $5.9 \pm 0.4^{\mathrm{a}, \mathrm{A}}$ & $0.6 \pm 0.2^{\mathrm{ab}, \mathrm{B}}$ \\
Jungle rubber & $53.9 \pm 3.7^{\mathrm{a}, \mathrm{B}}$ & $5.6 \pm 0.3^{\mathrm{a}, \mathrm{B}}$ & $1.3 \pm 0.6^{\mathrm{a}, \mathrm{A}}$ \\
Rubber & $72.6 \pm 5.7^{\mathrm{a}, \mathrm{A}}$ & $4.1 \pm 0.6^{\mathrm{b}, \mathrm{A}}$ & $0.1 \pm 0.0^{\mathrm{b}, \mathrm{A}}$ \\
Oil palm & $59.0 \pm 6.7^{\mathrm{a}, \mathrm{A}}$ & $4.2 \pm 1.1^{\mathrm{b}, \mathrm{B}}$ & $0.6 \pm 0.4^{\mathrm{ab}, \mathrm{A}}$ \\
\hline
\end{tabular}


Competing interests. The authors declare that they have no conflict of interest.

Acknowledgements. We thank the village leaders, local plot owners, PT REKI, PTPN VI and the Bukit Duabelas National Park for granting us access and use of their properties. This study was financed by the German Research Foundation (Deutsche Forschungsgemeinschaft, DFG) as part of the project A05 (CRC 990/2) in the framework of the German-Indonesian Collaborative Research Center 990: Ecological and Socioeconomic Function of Tropical Lowland Rainforest Transformation Systems. We are especially grateful to our Indonesian assistants, Edward Januarlin Siahaan, Nelson Apriadi Silalahi, Ardi, Fahrurrozy, Edi, Bayu Puja Kesuma, Basri, Darwis and Suriana, as well as all the rangers of the protected forest areas. We also acknowledge project A03 for helping in part of the gas sampling in PTPN VI, and both A03 and the Indonesian Meteorological, Climatological and Geophysical Agency for climatic data as well as the other members of project A05 (Allen et al., 2015) for the soil physical and biochemical data (Appendix Table A2); we also acknowledge project B04 (Kotowska et al., 2015) and B06 (Rembold et al., unpublished data) for providing the vegetation data. We thank Norman Loftfield, Oliver van Straaten, Andrea Bauer, Kerstin Langs and Martina Knaust (University of Göttingen, Germany) for their assistance with laboratory analyses. This study was conducted using the research permits (210/SIP/FRP/SM/VI/2012 and 45/EXT/SIP/FRP/SM/V/2013) from the Ministry of Research and Technology of Indonesia (RISTEK) and the collection permits (2703/IPH.1/KS.02/XI/2012 and S.13/KKH-2/2013) from the Indonesian Institute of Sciences (LIPI) and the Ministry of Forestry (PHKA).

This open-access publication was funded by the University of Göttingen.

Edited by: P. Stoy

Reviewed by: Y. A. Teh and one anonymous referee

\section{References}

Aini, F. K., Hergoualc'h, K., Smith, J. U., and Verchot, L.: Nitrous oxide emissions along a gradient of tropical forest disturbance on mineral soils in Sumatra, Agr. Ecosyst. Environ., 214, 107-117, https://doi.org/10.1016/j.agee.2015.08.022, 2015.

Allen, K., Corre, M. D., Tjoa, A., and Veldkamp, E.: Soil nitrogencycling responses to conversion of lowland forests to oil palm and rubber plantations in Sumatra, Indonesia, PLoS ONE, 10, e0133325, https://doi.org/10.1371/journal.pone.0133325, 2015.

BPS (Badan Pusat Statistik): Indonesian oil palm statistics 2013, BPS, Jakarta, Indonesia, 2014.

BPS (Badan Pusat Statistik): Plantation area by province and crops, Indonesia, 2012-2014, available at: http://www.bps.go.id/ linkTableDinamis/view/id/838 (last access: 7 April 2016), $2016 \mathrm{a}$.

BPS (Badan Pusat Statistik): Production of plantation crops by province and crops, Indonesia, 2012-2014, available at: http: //www.bps.go.id/linkTableDinamis/view/id/839 (last access: 27 June 2016), 2016b.
Breuer, L., Papen, H., and Butterbach-Bahl, K.: $\mathrm{N}_{2} \mathrm{O}$ emission from tropical forest soils of Australia, J. Geophys. Res., 105, 26353 26367, https://doi.org/10.1029/2000JD900424, 2000.

Castaldi, S., Bertolini, T., Valente, A., Chiti, T., and Valentini, R.: Nitrous oxide emissions from soil of an African rain forest in Ghana, Biogeosciences, 10, 4179-4187, https://doi.org/10.5194/bg-10-4179-2013, 2013.

Conrad, R.: Compensation concentration as critical variable for regulating the flux of trace gases between soil and atmosphere, Biogeochemistry, 27, 155-170, https://doi.org/10.1007/BF00000582, 1994.

Conrad, R.: Soil microorganisms as controllers of atmospheric trace gases $\left(\mathrm{H}_{2}, \mathrm{CO}, \mathrm{CH}_{4}, \mathrm{OCS}, \mathrm{N}_{2} \mathrm{O}\right.$, and $\left.\mathrm{NO}\right)$, Microbiol. Rev., 60, 609-640, 1996.

Corre, M. D., Veldkamp, E., Arnold, J., and Wright, S. J.: Impact of elevated $\mathrm{N}$ input on soil $\mathrm{N}$ cycling and losses in old-growth lowland and montane forests in Panama, Ecology, 91, 1715-1729, https://doi.org/10.1890/09-0274.1, 2010.

Corre, M. D., Sueta, J. P., and Veldkamp, E.: Nitrogen-oxide emissions from tropical forest soils exposed to elevated nitrogen input strongly interact with rainfall quantity and seasonality, Biogeochemistry, 118, 103-120, https://doi.org/10.1007/s10533013-9908-3, 2014.

Crawley, M. J.: The R Book, John Wiley \& Sons Ltd, Chichester, UK, 2007.

Davidson, E. A. and Kingerlee, W.: A global inventory of nitric oxide emissions from soils, Nutr. Cycl. Agroecosys., 48, 37-50, https://doi.org/10.1023/A:1009738715891, 1997.

Davidson, E. A., Keller, M., Erickson, H. E., Verchot, L. V., and Veldkamp, E.: Testing a conceptual model of soil emissions of nitrous and nitric oxides, Bioscience, 50(8), 667-680, https://doi.org/10.1641/00063568(2000)050[0667:TACMOS]2.0.CO;2, 2000.

Davidson, E. A., Ishida, F. Y., and Nepstad, D. C.: Effects of an experimental drought on soil emissions of carbon dioxide, methane, nitrous oxide, and nitric oxide in a moist tropical forest, Glob. Change Biol., 10, 718-730, https://doi.org/10.1111/j.13652486.2004.00762.x, 2004.

FAO (Food and Agricultural Organization): FAOSTAT database, available at: http://faostat3.fao.org/browse/Q/QC/E (last access: 22 March 2016), 2016.

Field, R. D., van der Werf, G. R., and Shen, S. S. P.: Human amplification of drought-induced biomass burning in Indonesia since 1960, Nat. Geosci., 2, 185-188, https://doi.org/10.1038/NGEO443, 2009.

Firestone, M. K. and Davidson, E. A.: Microbiological basis of NO and $\mathrm{N}_{2} \mathrm{O}$ production and consumption in soil, in: Exchange of trace gases between terrestrial ecosystems and the atmosphere, edited by: Andreae, M. O. and Schimel, D. S., John Wiley \& Sons Ltd, New York, USA, 7-21, 1989.

Gaveau, D. L. A, Salim, M. A, Hergoualc'h, K., Locatelli, B., Sloan, S., Wooster, M., Marlier, M. E., Molidena, E., Yaen, H., DeFries, R., Verchot, L., Murdiyarso, D., Nasi, R., Holmgren, P., and Sheil, D.: Major atmospheric emissions from peat fires in Southeast Asia during non-drought years: evidence from the 2013 Sumatran fires, Sci. Rep., 4, 1-7, https://doi.org/10.1038/srep06112, 2014.

Hassler, E., Corre, M. D., Tjoa, A., Damris, M., Utami, S. R., and Veldkamp, E.: Soil fertility controls soil-atmosphere car- 
bon dioxide and methane fluxes in a tropical landscape converted from lowland forest to rubber and oil palm plantations, Biogeosciences, 12, 5831-5852, https://doi.org/10.5194/bg-125831-2015, 2015.

Heinen, M.: Simplified denitrification models: Overview and properties, Geoderma, 133, 444-463, https://doi.org/10.1016/j.geoderma.2005.06.010, 2006.

Hewitt, C. N., MacKenzie, A. R., Di Carlo, P., Di Marco, C. F., Dorsey, J. R., Evans, M., Fowler, D., Gallagher, M. W., Hopkins, J. R., Jones, C. E., Langford, B., Lee, J. D., Lewis, A. C., Lim, S. F., McQuaid, J., Misztal, P., Moller, S. J., Monks, P. S., Nemitz, E., Oram, D. E., Owen, S. M., Phillips, G. J., Pugh, T. A. M., Pyle, J. A., Reeves, C. E., Ryder, J., Siong, J., Skiba, U., and Stewart, D. J.: Nitrogen management is essential to prevent tropical oil palm plantations from causing groundlevel ozone pollution, P. Natl. Acad. Sci. USA., 106, 1844718451, https://doi.org/10.1073/pnas.0907541106, 2009.

Hoben, J. P., Gehl, R. J., Millar, N., Grace, P. R., and Robertson, G. P.: Nonlinear nitrous oxide $\left(\mathrm{N}_{2} \mathrm{O}\right)$ response to nitrogen fertilizer in on-farm corn crops of the US Midwest, Glob. Change Biol., 17, 1140-1152, https://doi.org/10.1111/j.13652486.2010.02349.x, 2011.

IPCC: Climate Change 2013: The physical science basis, contribution of working group I to the fifth assessment report of the intergovernmental panel on climate change, Cambridge University Press, Cambridge, UK, New York, USA, 2013.

Ishizuka, S., Tsuruta, H., and Murdiyarso, D.: An intensive field study on $\mathrm{CO}_{2}, \mathrm{CH}_{4}$, and $\mathrm{N}_{2} \mathrm{O}$ emissions from soils at four landuse types in Sumatra, Indonesia, Global Biogeochem. Cy., 16, 22-1-22-11, https://doi.org/10.1029/2001GB001614, 2002.

Ishizuka, S., Iswandi, A., Nakajima, Y., Yonemura, S., Sudo, S., Tsuruta, H., and Murdiyarso, D.: The variation of greenhouse gas emissions from soils of various land-use/cover types in Jambi province, Indonesia, Nutr. Cycl. Agroecosys., 71, 17-32, https://doi.org/10.1007/s10705-004-0382-0, 2005.

Jacob, D. and Bakwin, P.: Cycling of $\mathrm{NO}_{x}$ in tropical forest canopies, in: Microbial production and consumption of greenhouse gases: methane, nitrogen oxides and halomethanes, edited by: Rogers, J. E. and Whitman, W. B., American Society for Microbiology, Washington, DC, USA, 237-253, 1991.

Keller, M. and Reiners, W. A.: Soil-atmosphere exchange of nitrous oxide, nitric oxide, and methane under secondary succession of pasture to forest in the Atlantic lowlands of Costa Rica, Global Biogeochem. Cy., 8, 399-409, https://doi.org/10.1029/94GB01660, 1994.

Keller, M., Varner, R., Dias, J. D., Silva, H., Crill, P., de Oliveira, R. C., and Asner, G. P.: Soil-atmosphere exchange of nitrous oxide, nitric oxide, methane, and carbon dioxide in logged and undisturbed forest in the Tapajos National Forest, Brazil, Earth Interact., 9, 1-28, https://doi.org/10.1175/EI125.1, 2005.

Koehler, B., Corre, M. D., Veldkamp, E., Wullaert, H., and Wright, S. J.: Immediate and long-term nitrogen oxide emissions from tropical forest soils exposed to elevated nitrogen input, Glob. Change Biol., 15, 2049-2066, https://doi.org/10.1111/j.13652486.2008.01826.x, 2009.

Kotowska, M. M., Leuschner, C., Triadiati, T., Meriem, S., and Hertel, D.: Quantifying above and belowground biomass carbon loss with forest conversion in tropical lowlands of
Sumatra (Indonesia), Glob. Change Biol., 21, 3620-3634, https://doi.org/10.1111/gcb.12979, 2015.

Kurniawan, S.: Conversion of lowland forests to rubber and oil palm plantations changes nutrient leaching and nutrient retention efficiency in highly weathered soils of Sumatra, Indonesia (Doctoral dissertation, Faculty of Forest Sciences and Forest Ecology, University of Goettingen), available at: http://hdl.handle.net/11858/ 00-1735-0000-0028-8706-8 (last access: 25 May 2016), 2016.

Lammel, G. and Graßl, H.: Greenhouse effect of $\mathrm{NO}_{x}$, Environ. Sci. Pollut. R., 2, 40-45, https://doi.org/10.1007/BF02987512, 1995.

Laumonier, Y., Uryu, Y., Stüwe, M., Budiman, A., Setiabudi, B., and Hadian, O.: Eco-floristic sectors and deforestation threats in Sumatra: Identifying new conservation area network priorities for ecosystem-based land use planning, Biodivers. Conserv., 19, 1153-1174, https://doi.org/10.1007/s10531-010-9784-2, 2010.

Lestari, R. K., Watanabe, M., Imada, Y., Shiogama, H., Field, R. D., Takemura, T., and Kimoto, M.: Increasing potential of biomass burning over Sumatra, Indonesia induced by anthropogenic tropical warming, Environ. Res. Lett., 9, 104010, https://doi.org/10.1088/1748-9326/9/10/104010, 2014.

Levine, J. S.: The 1997 fires in Kalimantan and Sumatra, Indonesia: Gaseous and particulate emissions, Geophys. Res. Lett., 26, 815818, https://doi.org/10.1029/1999GL900067, 1999.

Margono, B. A., Turubanova, S., Zhuravleva, I., Potapov, P., Tyukavina, A., Baccini, A., Goetz, S., and Hansen, M. C.: Mapping and monitoring deforestation and forest degradation in Sumatra (Indonesia) using Landsat time series data sets from 1990 to 2010, Environ. Res. Lett., 7, 034010, https://doi.org/10.1088/1748-9326/7/3/034010, 2012.

Matson, P. A., Billow, C., Hall, S., and Zachariassen, J.: Fertilization practices and soil variations control nitrogen oxide emissions from tropical sugar cane, J. Geophys. Res.-Atmos., 101, 18533-18545, https://doi.org/10.1029/96JD01536, 1996.

Müller, A. K., Matson, A. L., Corre, M. D., and Veldkamp, E.: Soil $\mathrm{N}_{2} \mathrm{O}$ fluxes along an elevation gradient of tropical montane forests under experimental nitrogen and phosphorus addition, Front. Earth Sci., 3, 1-12, https://doi.org/10.3389/feart.2015.00066, 2015.

Pahan, I.: Panduan lengkap kelapa sawit [translation: Complete guide to oil palm], Penebar Swadaya, Jakarta, Indonesia, 2010.

Pennock, D. J. and Corre, M. D.: Development and application of landform segmentation procedures, Soil Till. Res., 58, 151-162, https://doi.org/10.1016/S0167-1987(00)00165-3, 2001.

Pilegaard, K.: Processes regulating nitric oxide emissions from soils, Philos. T. R. Soc. B, 368, 20130126, https://doi.org/10.1098/rstb.2013.0126, 2013.

Purbopuspito, J., Veldkamp, E., Brumme, R., and Murdiyarso, D.: Trace gas fluxes and nitrogen cycling along an elevation sequence of tropical montane forests in Central Sulawesi, Indonesia, Global Biogeochem. Cy., 20, GB3010, https://doi.org/10.1029/2005GB002516, 2006.

R Development Core Team: R: A language and environment for statistical computing, R Foundation for Statistical Computing, Vienna, Austria, 2015.

Ravishankara, A. R., Daniel, J. S., and Portmann, R. W.: Nitrous oxide $\left(\mathrm{N}_{2} \mathrm{O}\right)$ : the dominant ozone-depleting substance emitted in the 21st century, Science, 326, 123-125, https://doi.org/10.1126/science.1176985, 2009. 
Skiba, U. and Smith, K. A.: The control of nitrous oxide emissions from agricultural and natural soils, Chemosphere, 2, 379-386, https://doi.org/10.1016/S1465-9972(00)00016-7, 2000.

Sparks, J. P., Monson, R. K., Sparks, K. L., and Lerdau, M.: Leaf uptake of nitrogen dioxide $\left(\mathrm{NO}_{2}\right)$ in a tropical wet forest: Implications for tropospheric chemistry, Oecologia, 127, 214-221, https://doi.org/10.1007/s004420000594, 2001.

Veldkamp, E. and Keller, M.: Nitrogen oxide emissions from a banana plantation in the humid tropics, J. Geophys. Res., 102, 15889-15898, 10.1029/97JD00767, 1997.

Veldkamp, E., Keller, M., and Nuñez, M.: Effects of pasture management on $\mathrm{N}_{2} \mathrm{O}$ and $\mathrm{NO}$ emissions from soils in the humid tropics of Costa Rica, Global Biogeochem. Cy., 12, 71-79, https://doi.org/10.1029/97GB02730, 1998.

Veldkamp, E., Purbopuspito, J., Corre, M. D., Brumme, R., and Murdiyarso, D.: Land use change effects on trace gas fluxes in the forest margins of Central Sulawesi, Indonesia, J. Geophys. Res., 113, G02003, https://doi.org/10.1029/2007JG000522, 2008.

Verchot, L. V., Davidson, E. A., Cattânio, J. H., Ackerman, I. L., Erickson, H. E., and Keller, M.: Land use change and biogeochemical controls of nitrogen oxide emissions from soils in eastern Amazonia, Global Biogeochem. Cy., 13, 31-46, https://doi.org/10.1029/1998GB900019, 1999.
Wang, Y. F., Owen, S. M., Li, Q. J., and Peñuelas, J.: Monoterpene emissions from rubber trees (Hevea brasiliensis) in a changing landscape and climate: chemical speciation and environmental control, Glob. Change Biol., 13, 2270-2282, https://doi.org/10.1111/j.1365-2486.2007.01441.x, 2007.

Werner, C., Zheng, X., Tang, J., Xie, B., Liu, C., Kiese, R., and Butterbach-Bahl, K.: $\mathrm{N}_{2} \mathrm{O}, \mathrm{CH}_{4}$ and $\mathrm{CO}_{2}$ emissions from seasonal tropical rainforests and a rubber plantation in Southwest China, Plant Soil, 289, 335-353, https://doi.org/10.1007/s11104006-9143-y, 2006.

Werner, C., Butterbach-Bahl, K., Haas, E., Hickler, T., and Kiese, R.: A global inventory of $\mathrm{N}_{2} \mathrm{O}$ emissions from tropical rainforest soils using a detailed biogeochemical model, Global Biogeochem. Cy., 21, GB3010, https://doi.org/10.1029/2006GB002909, 2007.

White, C. S.: The role of monoterpenes in soil nitrogen cycling processes in ponderosa pine - results from laboratory bioassays and field studies, Biogeochemistry, 12, 43-68, https://doi.org/10.1007/BF00002625, 1991.

Yashiro, Y., Kadir, W. R., Adachi, M., Okuda, T., and Koizumi, H.: Emission of nitrous oxide from tropical forest and plantation soils in Peninsular Malaysia, Tropics, 17, 17-23, https://doi.org/10.3759/tropics.17.17, 2008. 